\title{
Pattern of sedimentation during the Late Paleozoic, Gondwanaland glaciation: An example from the Talchir Formation, Satpura Gondwana basin, central India
}

\author{
Chandan Chakraborty ${ }^{1, *}$ and Sanjoy Kumar Ghosh ${ }^{2}$ \\ ${ }^{1}$ Geological Studies Unit, Indian Statistical Institute, 203 B.T. Road, Kolkata 700108 , India. \\ ${ }^{2}$ Shell International Exploration and Production Inc. WCK\# 6380, 200 North Dairy Ashford, \\ Houston, Texas 77079, USA. \\ *e-mail: chandan@isical.ac.in
}

The Talchir Formation of Permian age is the lowermost lithostratigraphic unit of the Indian Gondwana successions preserving a record of the Late Paleozoic glaciation that affected the whole Gondwanaland. The formation unconformably overlies the Precambrian basement in all the Gondwana basins of India, and marks initiation of sedimentation after a long hiatus since the Proterozoic. The Talchir Formation of the Satpura Gondwana basin of central India shows features diagnostic of deposition under glacial regime such as the presence of diamictites, boulder pavements, bedding plane striation, faceted/striated gravels, bullet-shaped clasts, dropstone, cryoturbation, etc. The Talchir strata of the Satpura basin, in addition to tidal signatures, contain marine bivalve and trace fossils. A proglacial marine environment is thus inferred for their deposition. The dominant lithologies are conglomerate, pebbly sandstone, sandstone and shale with little limestone, which can be classified into the following major facies:

- matrix-supported conglomerate,

- clast-supported conglomerate,

- cross-stratified, channel form pebbly sandstone,

- hummocky, swaley or low-angle cross-stratified pebbly and non-pebbly sandstone,

- turbidite/tempestite sheet sandstone,

- massive to fissile, green to black claystone with carbonate layers and nodules.

The conglomerates are interpreted as deposits of a spectrum of sub-aqueous sediment gravity flows including debris flow, hyperconcentrated/concentrated density flow and grain flow. The crossstratified pebbly sandstone bodies, on the other hand, represent braidplain delta deposits of glacial outwash origin. Hummocky, swaley, low-angle cross-stratified sediment bodies were deposited by storm-generated combined flows in a shoreface setting. In contrast, the sheet sandstone bodies are products of turbidity currents and storm-induced density currents in an inner shelf setting below fair weather wave base. The claystone facies is interpreted as a product of suspension fallout from hypopycnal sediment plumes in the outer shelf domain below storm wave base. All the lithofacies described above occur repetitively in the succession. Three facies-associations have been recognized in the Talchir Formation, representing ice-contact fandelta, outwash braidplain delta and a virtually ice-free, non-deltaic open marine realm. The different marine facies of the Talchir Formation define a number of shallowing-upward packages, which are arranged in the succession with a retrogradational trend to result in an overall fining- and deepening-upward succession. The overlying coal-bearing Barakar Formation has been interpreted to have formed in a tide-wave influenced

Keywords. Gondwana glaciation; glacio-marine sedimentation; Talchir Formation; Satpura basin. 
deltaic setting with a marine, prodeltaic part. The strata that are transitional between Talchir and Barakar Formations show preservation of abundant plant materials suggesting gradual warming. The three facies-associations of the Talchir Formation also point towards progressive decrease in the intensity of glacial activity, inducing changes in the paleogeography from ice-contact depositional environment to an eventually relatively ice-free, open marine condition.

\section{Introduction}

During the late Paleozoic and early Mesozoic period Gondwanaland, constituted by the present day - South America, Africa, India, Australia and Antarctica - experienced a number of major geological events, the signatures of which are present in the rock record of all the continents. These include:

- wide-spread, continental glaciation,

- development of intracratonic sedimentary basins containing coal-bearing strata, known as Gondwana basins, and

- huge eruption of continental flood basalts (Hobday 1987; Veevers and Tewari 1995; Veevers 2004).

In peninsular India, the Gondwana successions $(\sim 1-4 \mathrm{~km}$ thick) accumulated in a number of discrete basins mostly during the periods from Permian to Triassic following a long hiatus since the Proterozoic (figure 1; Robinson 1967; Veevers and Tewari 1995; Chakraborty et al 2003).

The Talchir Formation of Permian age is the lowermost lithostratigraphic unit of the Indian Gondwana succession (figure 1). The formation unconformably overlies the Precambrian basement in all the Gondwana basins of India, showing more or less uniform and distinctive characteristics. Distinctive characters include omnipresence of diamictites, similar fossil assemblages, and features diagnostic of deposition under glacial regime (Veevers and Tewari 1995). Strata of similar characteristics and age are also found in Australia, Africa, South America and Antarctica that along with India constituted the supercontinent Gondwanaland during the Permo-Carboniferous period (Hobday 1987; Veevers 2004). It is generally conceived that the Talchir and the other similar strata of the Gondwanaland assembly were formed during a period of continental glacial events (Crowell and Frakes 1975; Veevers and Powell 1987; Crowell 1995; Gonzalez-Bonorino and Eyles 1995; Eyles et al 1998, 2002, 2003). In this paper we present a detailed sedimentological analysis of the Talchir Formation of the Satpura Gondwana basin and decipher the depositional record of glacially influenced sedimentation in an intracontinental basin of the Indian subcontinent during the Permian glacial event.

\section{Geological background of the Satpura basin}

The Satpura basin is the westernmost of the series of basins occurring along the Narmada-SonDamodar valley, which also marks the junction of the Pranhita-Godavari valley and Narmarda-SonDamodar valley (figure 1). The basin is filled with ca. 5-km thick siliciclastic succession ranging in age from Permian to Cretaceous (Chakraborty and Ghosh 2005).

The Satpura basin $(\sim 200 \mathrm{~km}$ long, $\sim 60 \mathrm{~km}$ wide) is rhomb-shaped, relatively long in the ENEWSW direction, and its longer sides are marked by the ENE-WSW trending Son-Narmada south fault and Tapti north fault in the north and south respectively (see Chakraborty and Ghosh 2005). These faults are subvertical near the surface and show evidence of strike-slip movements (Crawford 1978; Das and Patel 1984; Biswas 1999, 2003) indicating the pull-apart origin of the basin (Chakraborty and Ghosh 2005). The regional strike of the basin-fill strata is NE-SW, and the regional $\operatorname{dip}\left(\sim 5^{\circ}\right)$ is northerly.

\section{Study area and methods}

In the Satpura basin the Talchir Formation is well exposed along the southern margin (figure 1) with a few outcrops at the northern boundary. The formation is overlain by the coal-bearing Barakar Formation. The present study is based on a number of river sections covering the entire outcrop of the Talchir Formation. The sections trend grossly across the structural strike exposing hundreds of meters of strata along the dip direction (figure 2). The rock successions were examined for preparation of lithological and sedimentological logs, characterisation of facies and their stacking pattern, as well as for facies-specific paleocurrent measurements. 


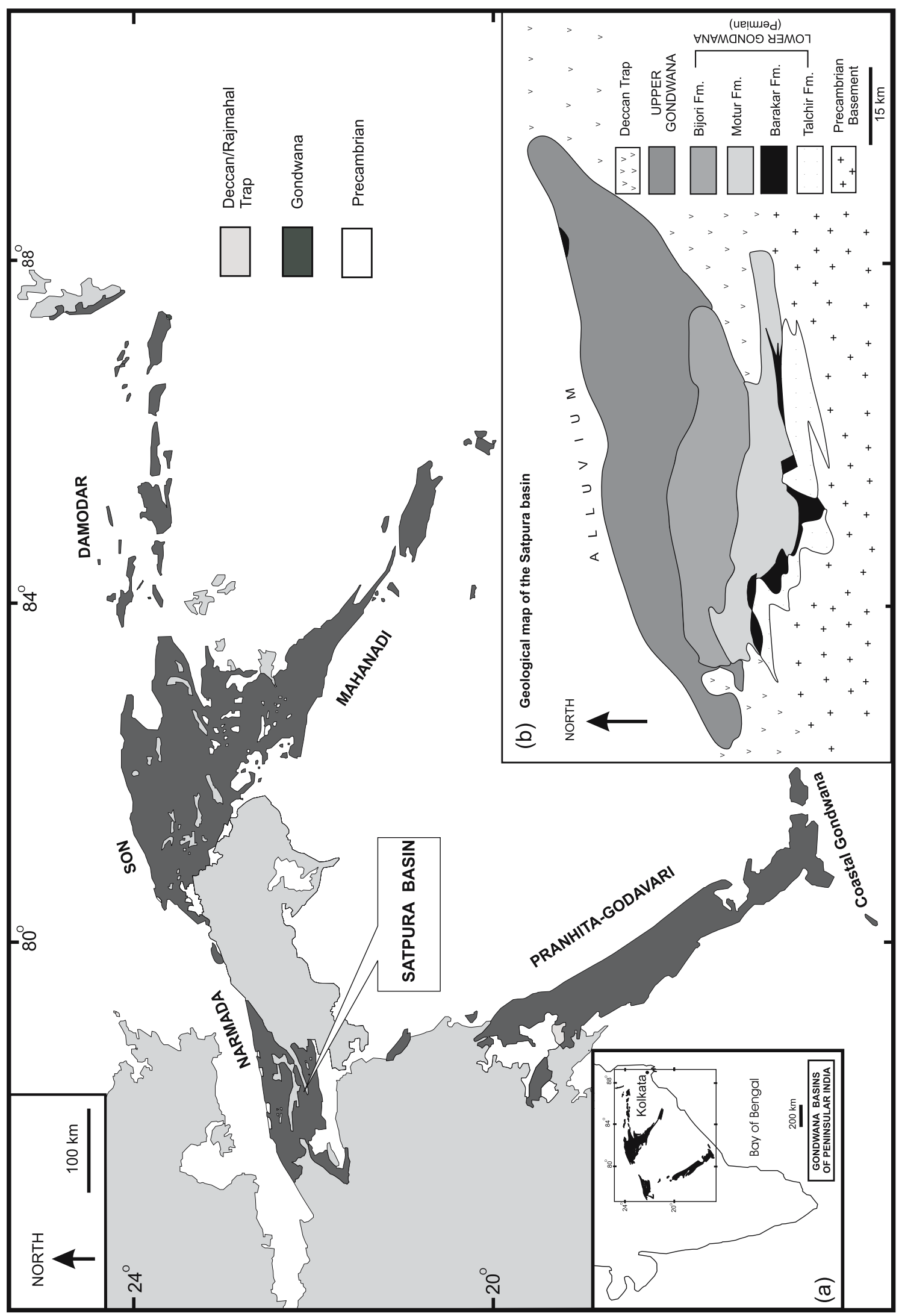

岁官

낭

章

2.

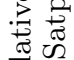

赵

$\exists$

త.?.ำ.

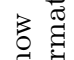

का

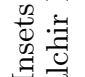

药

品

ॠ

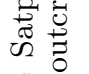

平

प्山。

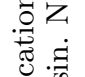

$\circ$

चี

敢

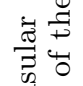

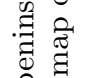

$\exists$.

$\therefore \frac{0}{8}$

:

ํํㄹ

흄

녕

过

造踪

记.]్తే

의

运

宽

ด

- 


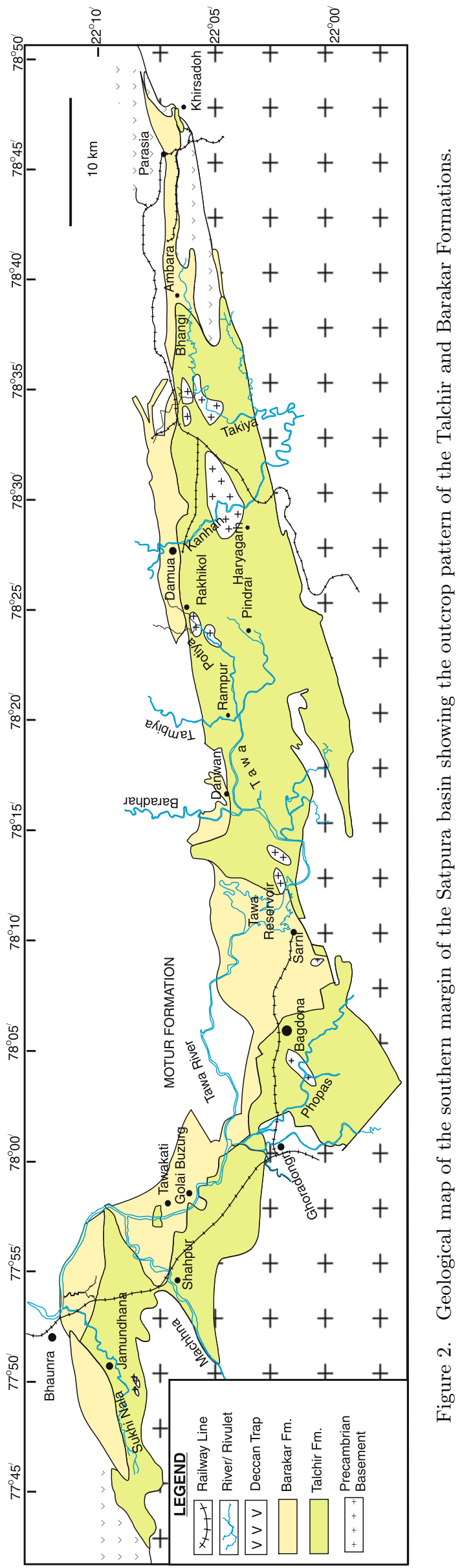

\section{Signatures of glacial influence in the Talchir strata}

Although continental glacial deposits (e.g., lodgment tillite) are not present, the Talchir Formation of the Satpura basin is replete with the diamictite lithology (Cashyap and Qidwai 1974). However, diamictites can have different types of genesis, and cannot be considered as an unambiguous evidence of glacial environment. Besides the presence of diamictite, there are several other features in the Talchir strata that may be attributed to deposition under the influence of glacial activity as enumerated below (cf. Gravenor et al 1984; Brodzikowski and Van Loon 1987; Eyles and Eyles 1992; Miller 1996).

- Striated Surfaces: Rectilinear striations are very common on the bedding planes of Talchir strata (figure 3a). The relief of the striation ranges from several $\mathrm{mm}$ to a few $\mathrm{cm}$. Such striations are known to be produced due to scratching of the substrate by moving glaciers. Striated surfaces are also present on the Precambrian basement rocks overlain by conglomerates representing the sediments carried down by the glacier.

- Striated Clasts: Striated gravels are abundant in the Talchir strata, which indicate that sediment particles underwent glacial abrasion (figure 3b).

- Faceted Clasts: Gravel-sized sediment particles produced due to glacial activity generally have smooth, polished, planar faces which are common in the Talchir strata.

- Bullet-shaped Clasts: Presence of bullet-shaped clasts in the Talchir Formation is another indication of glacial activity (figure 3c).

- Dropstone Structure: Individual gravel-sized sediment particles embedded within floating icebergs may be liberated and fall through the water column and settle on the sediment substrate, and are called dropstones. The diagnostic features of dropstones are bending of underlying laminae and the draping nature of overlying laminae, features which are abundant in the Talchir Formation (figure 3d).

- Dump Structure: In contrast to dropstone structure, dump structures represent isolated pods of gravel within finer-grained sediments formed due to the falling of a lump of sediment particles from a floating iceberg (Thomas and Connell 1985), and are common in the Talchir Formation (figure 3e).

- Boulder Pavement: Boulder pavements are smoothened surfaces strewn with large boulders and are a conspicuous feature of glacial environment. In the Talchir Formation many bedding planes are marked by occurrence of randomly distributed large boulders (figure 3f). 


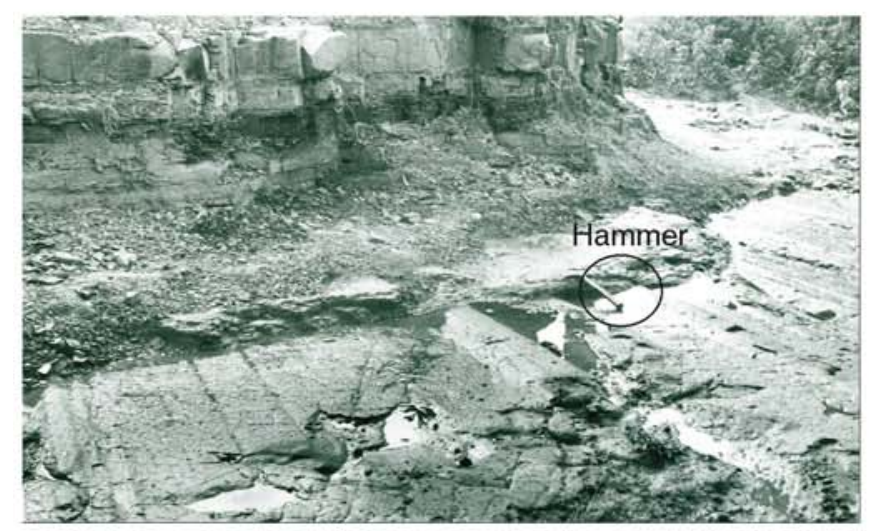

(a)

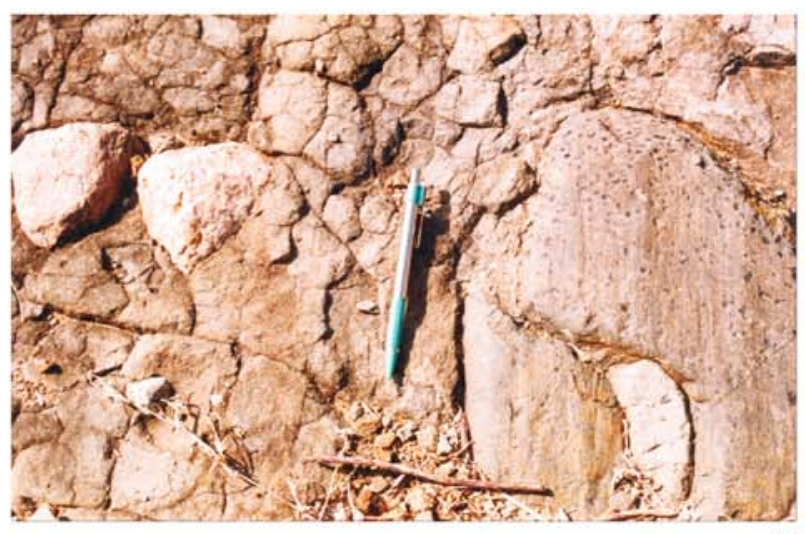

(b)
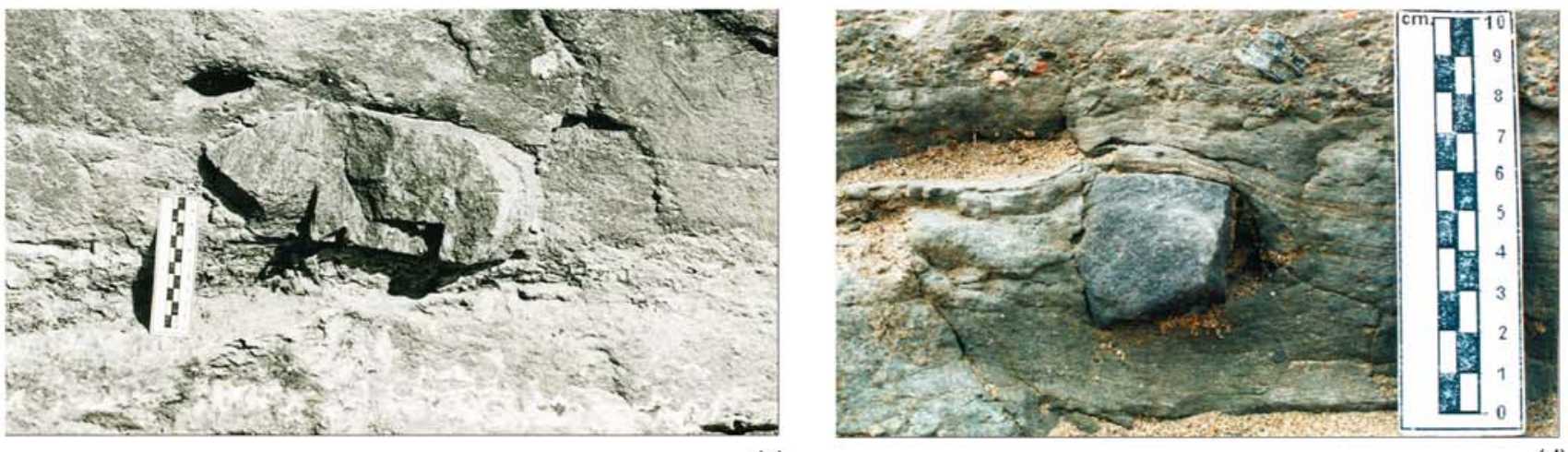

(c)

(d)
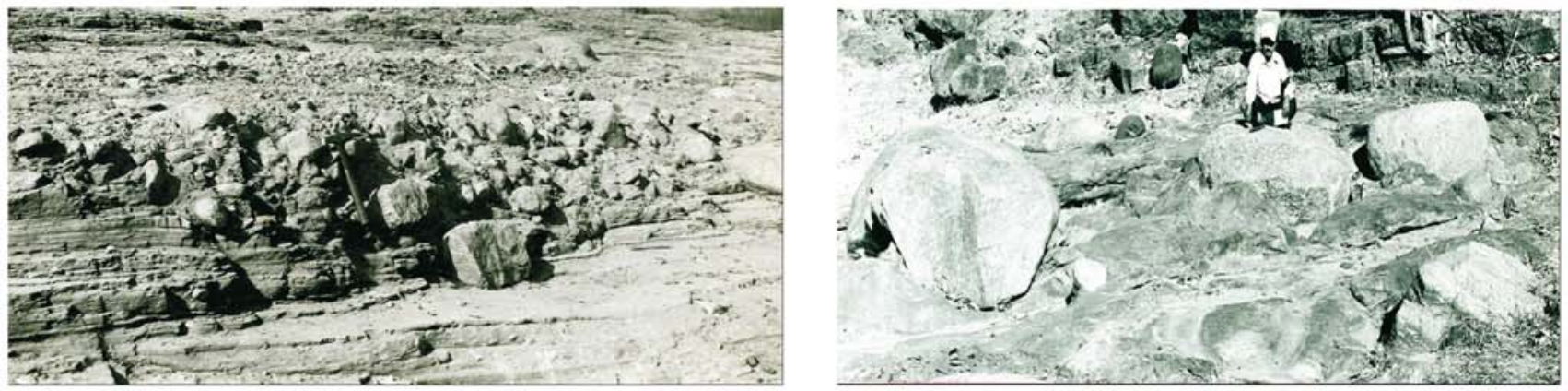

(e)
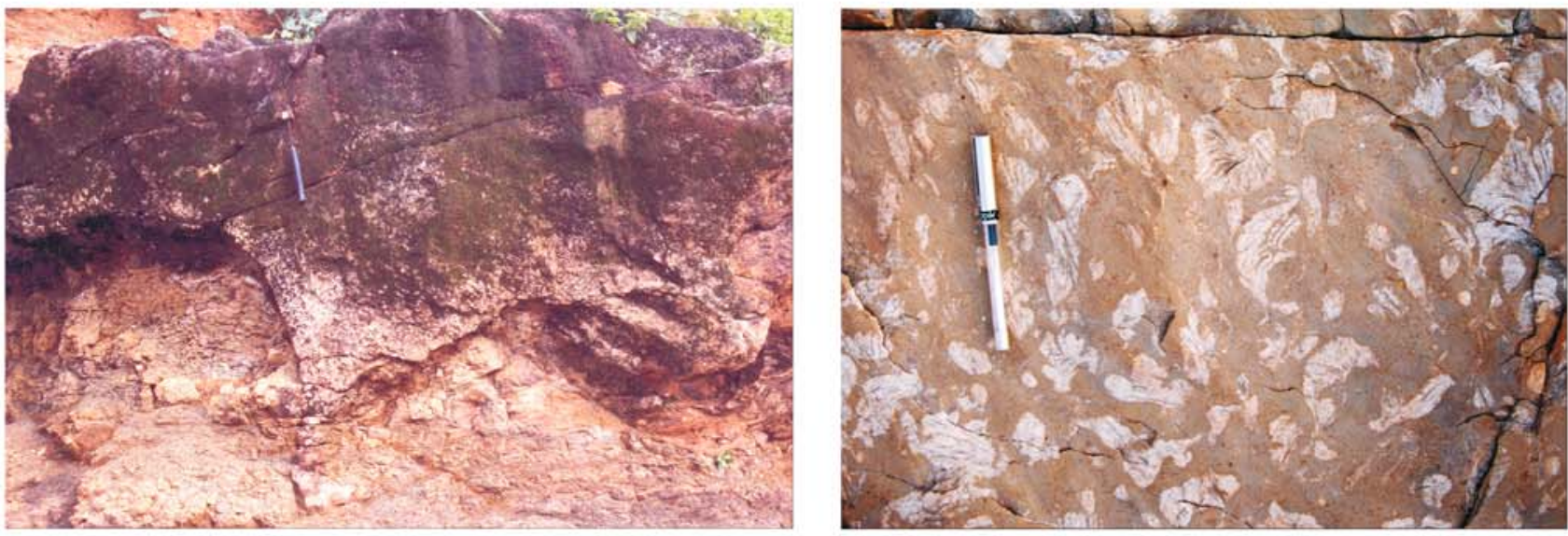

(g)

Figure 3. Diagnostic features of glacial sedimentation observed in the Talchir Formation of the Satpura basin. See text for details. 

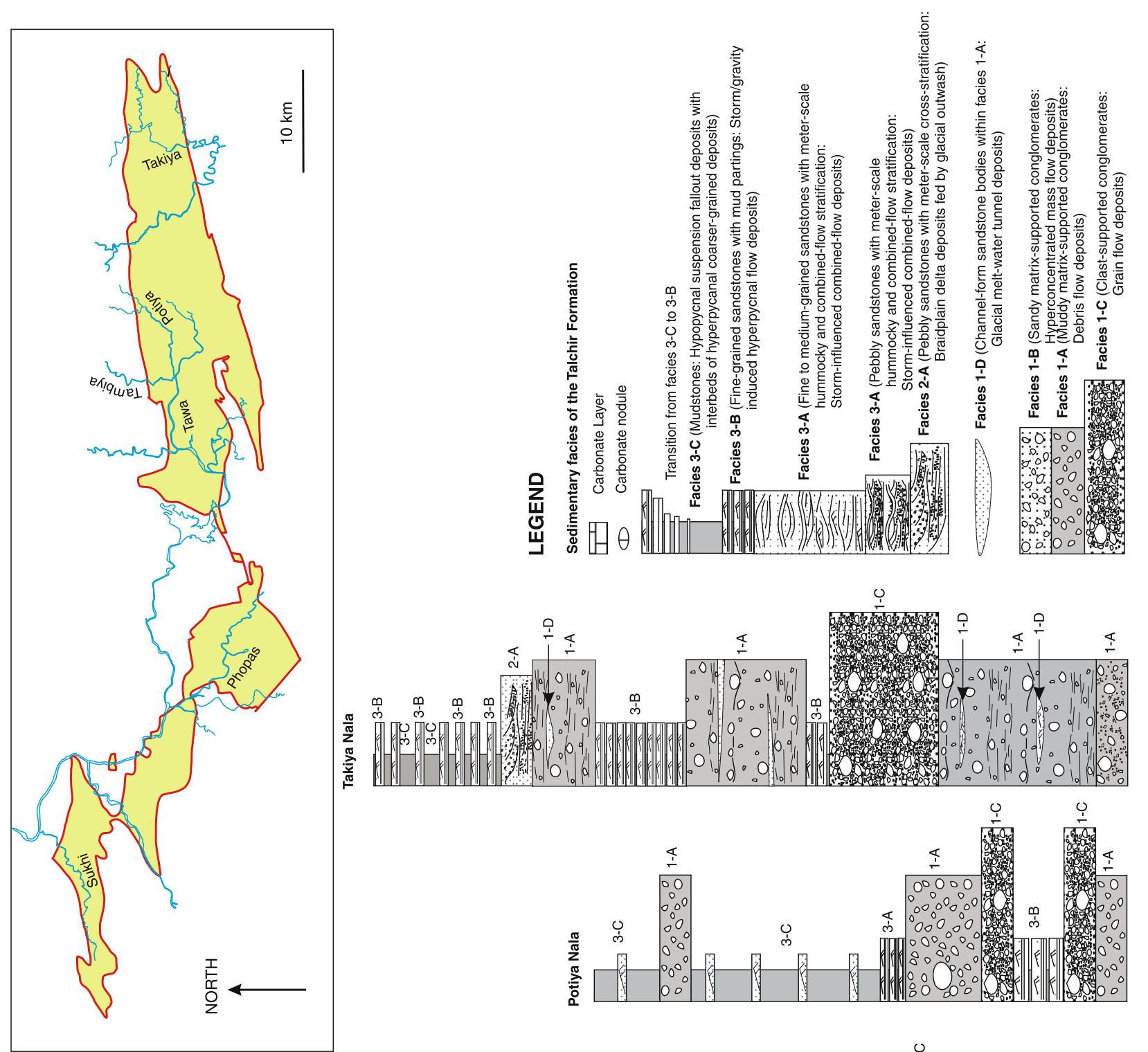

D
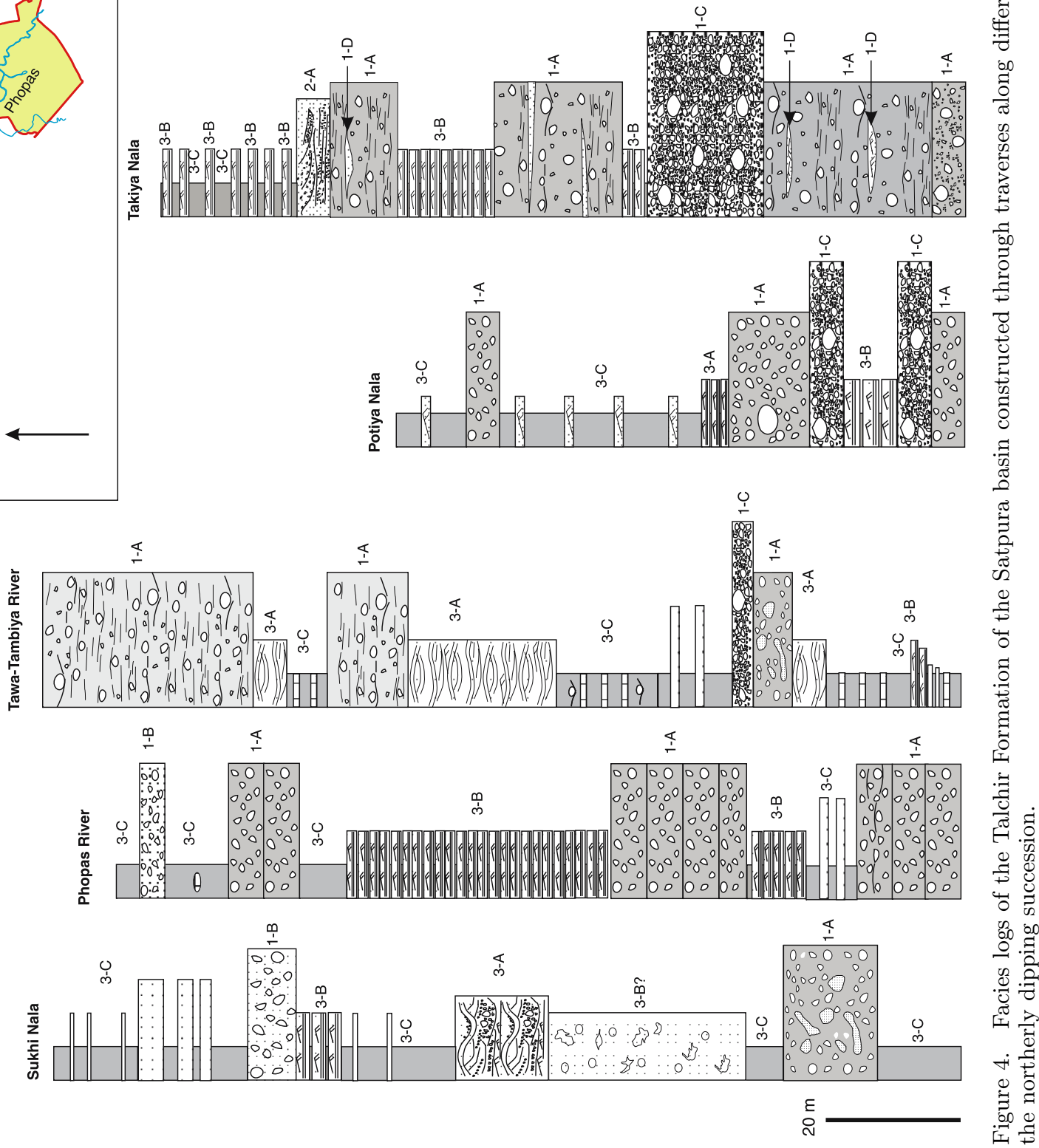
- Ice-wedge Structure: Contraction of sediment piles due to frosting often leads to formation of cracks that appear as upward widening wedgeshaped voids in profile. Following melting of ice, these voids are filled with sediments representing ice-wedge casts that are common in the Talchir Formation (figure 3g).

- Glaciotectonism and Cryoturbation: The traction exerted by glacier ice on pre-existing sedimentary strata induces deformation of varying intensities (Jones and Preston 1987). The deformation structures include fractures, micro faults, boudins, folds, etc. Ice action also leads to complete fluidization of soft-sediments leading to disruption of the sediment pile (cryoturbation; figure $3 \mathrm{~h}$ ). All these features abound in the Talchir Formation.

\section{Facies associations and paleogeography}

In the Satpura basin, the Permian Talchir strata contain bivalves, trace fossils, microfossils including palynomorphs indicating sedimentation in a marine regime (cf. Ghosh 2003). Complying with the glacial-diagnostic features mentioned above, a proglacial marine environment is thus inferred for the deposition of the Talchir strata (cf. Casshyap and Qidwai 1974). The Talchir lithologies include conglomerate, pebbly sandstone, sandstone and shale with little limestone. A number of marine sedimentary facies comprise the Talchir succession bearing signatures of accumulation in shoreface and shelf settings by basinal agents (figure 4). In addition, there are different types of glacigenic sediment gravity flow deposits (figure 4). Altogether, three facies associations have been recognized as described below. Each association represents a specific paleogeographic setting. The Talchir Formation gives way to the overlying Barakar Formation without any major depositional break (Ghosh et al 2004). Presence of coal/carbonaceous shale and absence of conglomerates distinguish the Barakar Formation which, in contrast to the Talchir Formation, was deposited in a wave/tide-influenced deltaic setting under a warm/humid climatic condition (Ghosh et al 2004).

\subsection{Facies association-1}

(Ice-contact fan delta deposits)

\section{1.a Facies- $1 A$ \\ (Sub-aqueous debris flow deposits)}

Description: This facies comprises two subfacies: (1) massive diamictite and (2) stratified diamictite. The massive diamictites appear as matrix-
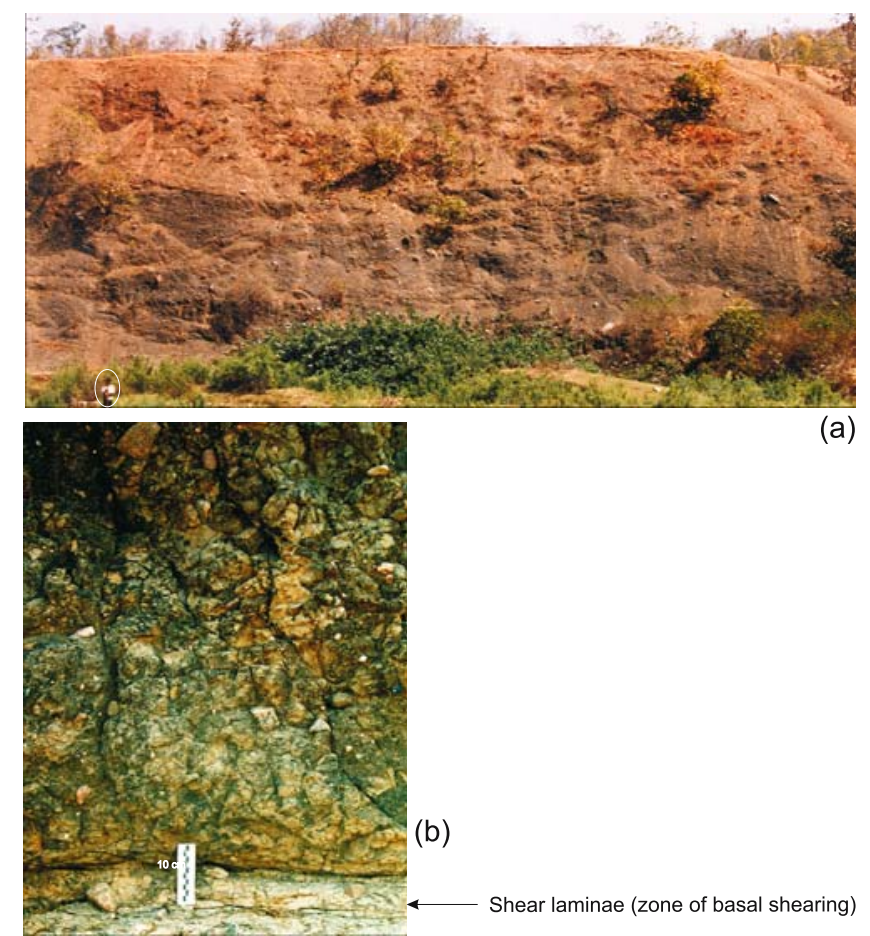

(a)

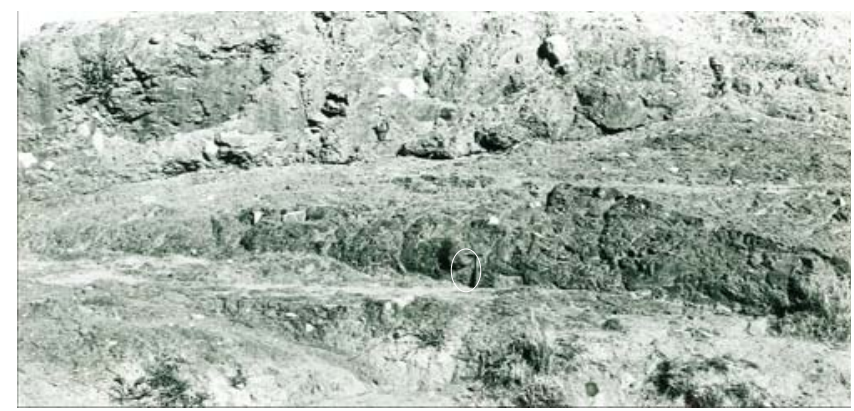

(c)

Figure 5. Muddy, matrix-supported conglomerates of facies 1-A. Note: random orientation of the clasts (a), basal shear laminae (b) and vertical stacking of beds (c).

supported, disorganized, ungraded conglomerates wherein gravel-sized (centimeter to meter scale) clasts float within a very hard mud-rich matrix (figure 5). Proportion of clasts is found to be around 5\%. Clasts are subangular to subrounded although well-rounded ones are not uncommon. The shape varies from equant to inequant, and discoidal to prolate ellipsoidal through spheroidal. Clast composition varies widely and includes gravels of massive granite, granite gneiss, schist, amphibolite, quartzite, limestone, etc. Intraformational clasts of conglomerate and sandstone also occur at places. The matrix shows weak foliage around large clasts, effectively wrapping them. These conglomerates occur as successively stacked beds with non-erosional bases ranging in thickness between $50 \mathrm{~cm}$ and a few meters (figure 5). The maximum thickness of individual stacks may be up to $20 \mathrm{~m}$. The bed boundaries are mostly diffuse, 


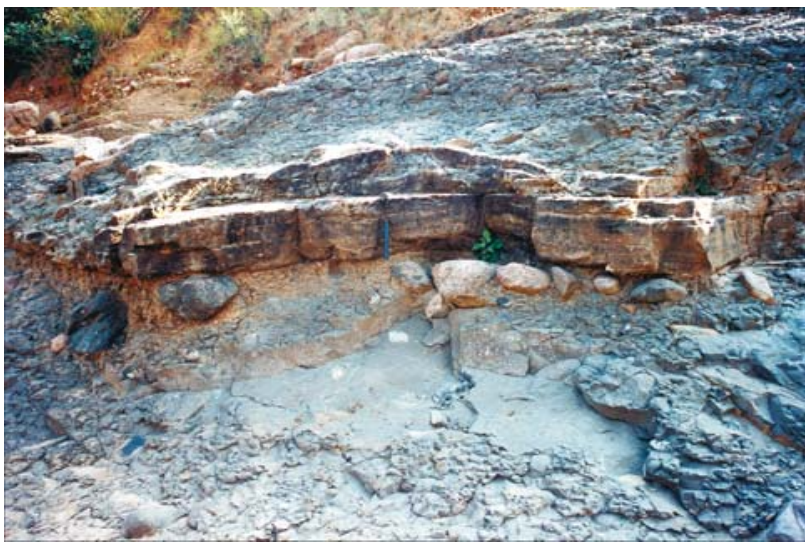

(a)

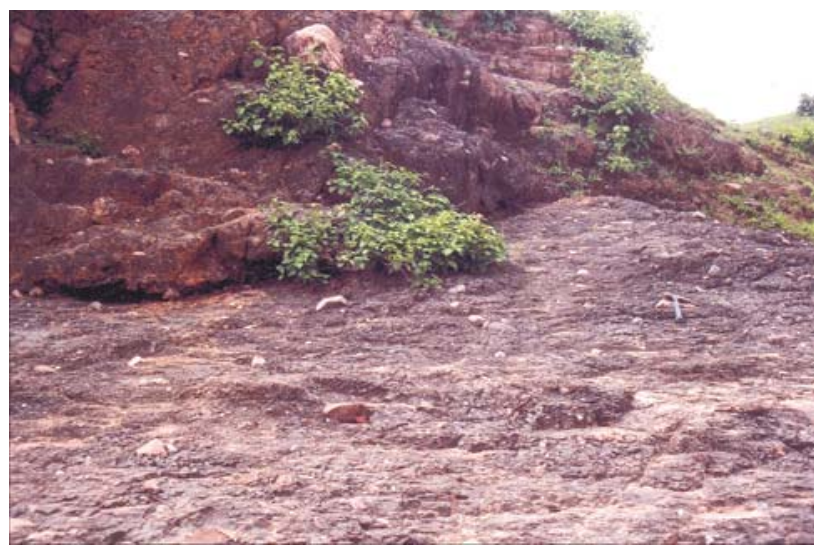

(c)

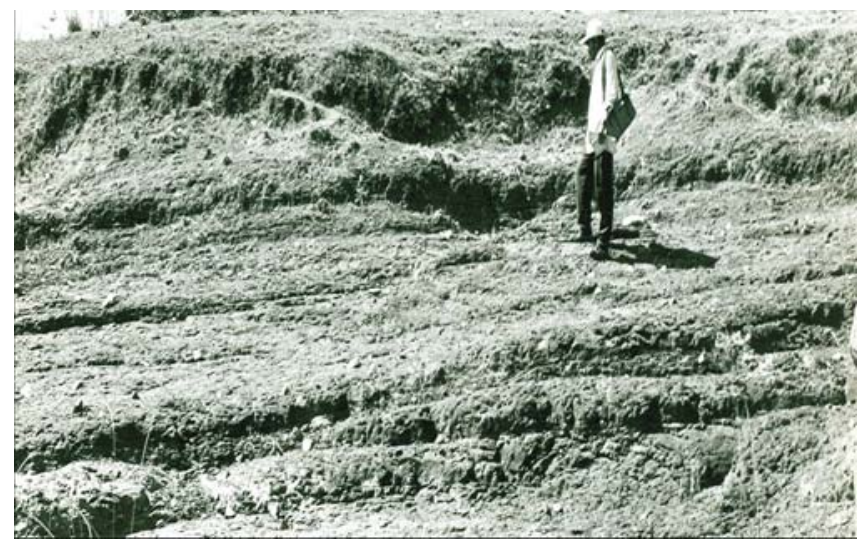

(b)

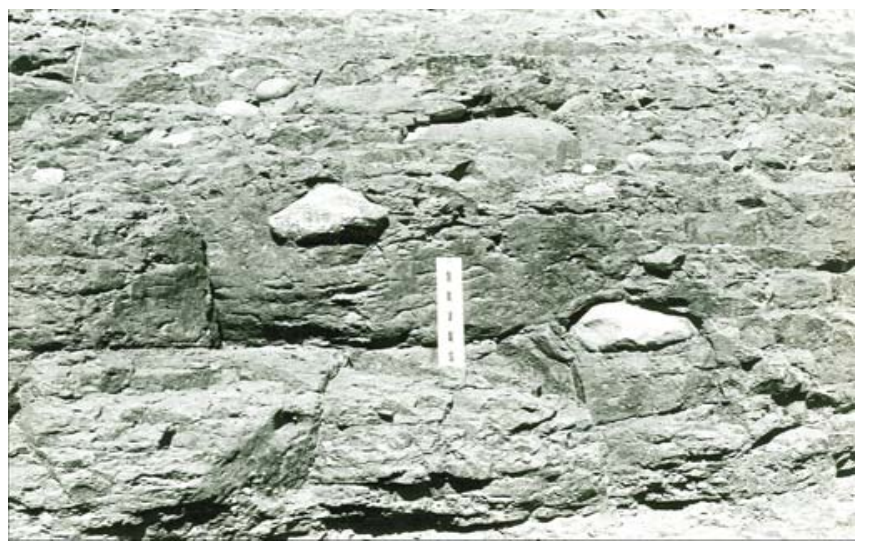

(d)

Figure 6. Stratified diamictites of facies 1-A. Note: cluster of dropstones and a hummocky cross-stratified sandstone bed at the interface of diamictite beds (a), laterally persistent stratification (b) and oriented pebbles (c, d). In (c) stratified diamictite is overlain by massive diamictite.

locally marked by sandstone interbeds or outsized gravels, and may not be discernible at places. In most cases, the clasts are randomly oriented. However, at the base of individual beds the elongate clasts appear to be oriented parallel to the bedding, which imparts a crude stratification (basal shear laminae; figure $5 \mathrm{~b}$ ).

The stratified diamictites, in appearance and mode of occurrence, are similar to the conglomerates described above with the exceptions that crude stratification is disernable in them and the elongate clasts show strong bedding-parallel fabric (figure 6).

Interpretation: It is inferred that the massive diamictites represent deposits of cohesive debris flows of plastic rheology (Mulder and Alexander 2001). High proportion of matrix, non-erosional bases, absence of grading, and random orientation of the gravel-sized clasts support this contention. The presence of appreciable mud in the matrix resulted into high viscosity supporting large clasts in suspension. Deposition mostly took place en-masse. The stack of beds developed from successive flows or due to punctuated bed aggradation (Wan and Wang 1994; Major 1997; Vallance and Scott 1997). The outsized boulders at the interfaces of beds are interpreted as dropstones (figure 6a). This implies subaqueous sediment gravity flows. Development of bedding-parallel orientation of clasts and fabric in the matrix at the basal parts of the beds was probably related to the high shear strain at the base of the debris flow (figure 6b). The stratified diamictites also represent subaqueous debris flow deposits. However, development of stratification in the matrix and clast fabric (figure $6 \mathrm{~b}, \mathrm{c}, \mathrm{d}$ ) in them suggests that high shear strain was restricted not only at the base of the flow but affected the entire flow (Enos 1977), probably due to the relatively less viscous nature of the matrix compared to the massive diamictities.

\section{1.b Facies-1B (Sub-aqueous hyperconcentrated density flow deposits)}

Description: This facies is represented by matrix-supported, ungraded conglomerates, and is 


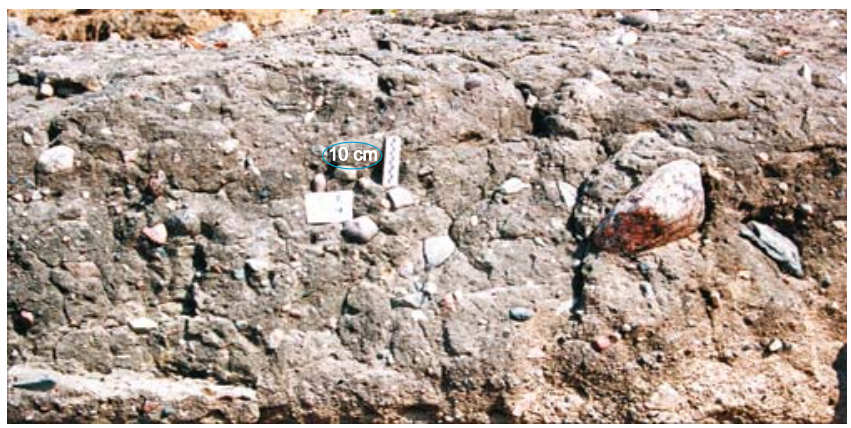

(a)

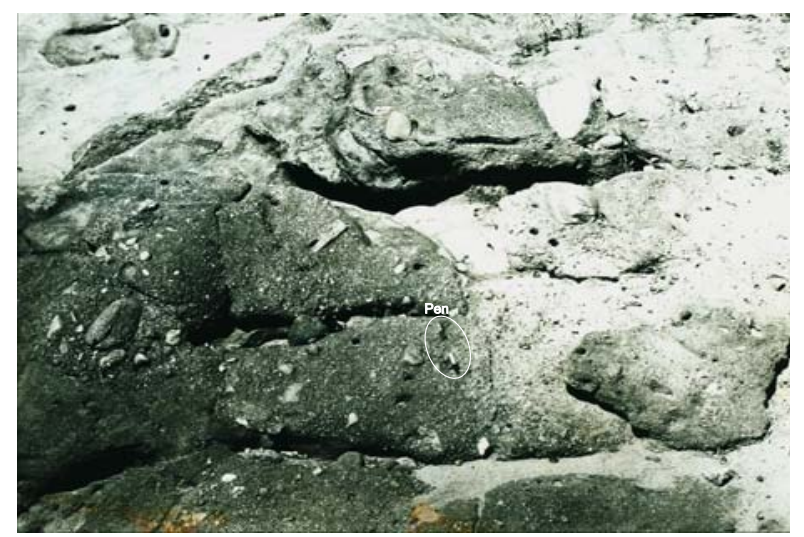

(c)

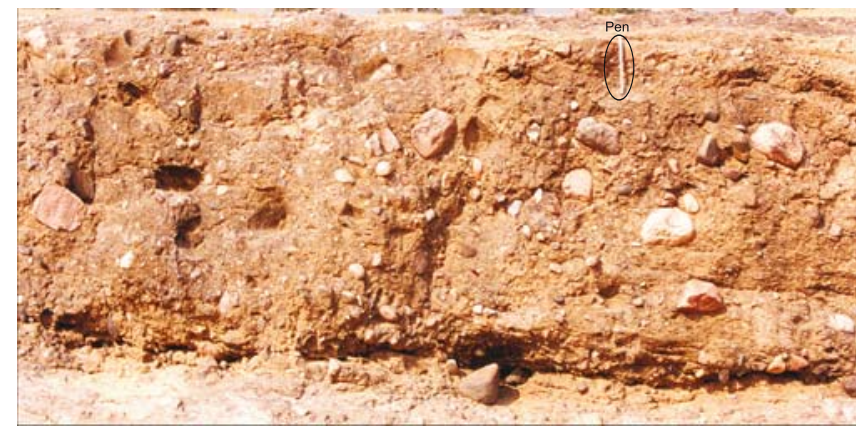

(b)

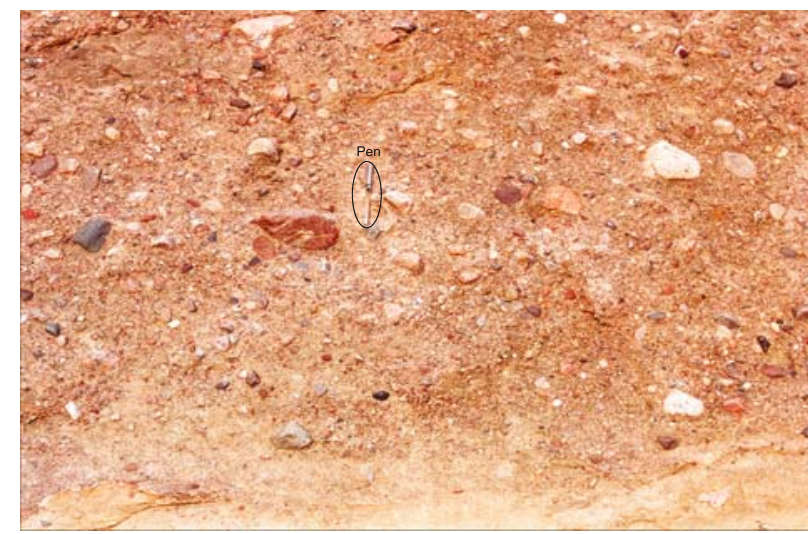

(d)

Figure 7. Sandy, matrix-supported conglomerates of facies 1-B. Note: crude fabric (a), preferred orientation of pebbles (b), vertical stacking of beds (c) and inverse grading (d).

distinguished from the facies-1A conglomerates by the sandier nature of the matrix (figure 7a). In other respects such as clast composition and shape, they are similar to the facies-1A conglomerates. Clasts float in the matrix and are mostly randomly oriented. However, at places they may define a shape fabric inclined at an angle to the bedding plane (figure $7 \mathrm{~b}$ ). These conglomerates occur as successively stacked beds ranging in thickness between $50 \mathrm{~cm}$ and $1 \mathrm{~m}$ (figure 7c). Inverse grading is developed locally (figure $7 \mathrm{~d}$ ). The maximum thickness of individual stacks may be about $5-10 \mathrm{~m}$ thick. The bed boundaries are mostly diffused and indiscernible unless intervened by sandstone beds or outsized boulders.

Interpretation: The features of the facies indicate deposition from cohesionless debris flows alias hyperconcentrated density flows with a rheology intermediate between plastic and granular. Clasts were supported by frictional strength of the matrix as well as grain collision (Sohn et al 1999; Mulder and Alexander 2001). A stack of beds resulted as deposition took place by the accretion of successive small-scale flow surges to the top of previous layers. Outsized boulders are interpreted as dropstones and point towards subaqueous condition. Development of clast fabric in some beds indicates high shear strain or development of traction carpets at the base (Hiscott 1994; Sohn 1997).

\section{1.c Facies-1C (Grain flow deposits)}

Description: This facies is represented by moderate to well-sorted, clast-supported conglomerates (figure 8). Clasts are within the gravel size range and sub-angular to sub-rounded with a few wellrounded ones. The clasts are in contact with each other in most cases, and the intergranular spaces are filled with coarse sands (figure 8b). Conglomerates occur as decimeter-scale beds with ill-defined, non-erosional boundaries (figure 8a). Inverse grading is very much conspicuous (figure 8b). In places, the clasts are imbricated. Outsized clasts occur at some of the bed boundaries.

Interpretation: This facies is interpreted as deposits of cohensionless, granular sediment gravity flow (grain flow; Lowe 1982; Mulder and Alexander 2001) wherein momentum transfer due to mutual interaction of the clasts was the dominant particle support mechanism. Development of inverse grading supports this contention. The imbrication probably resulted from tiling of clasts during flow. Deposition took place 


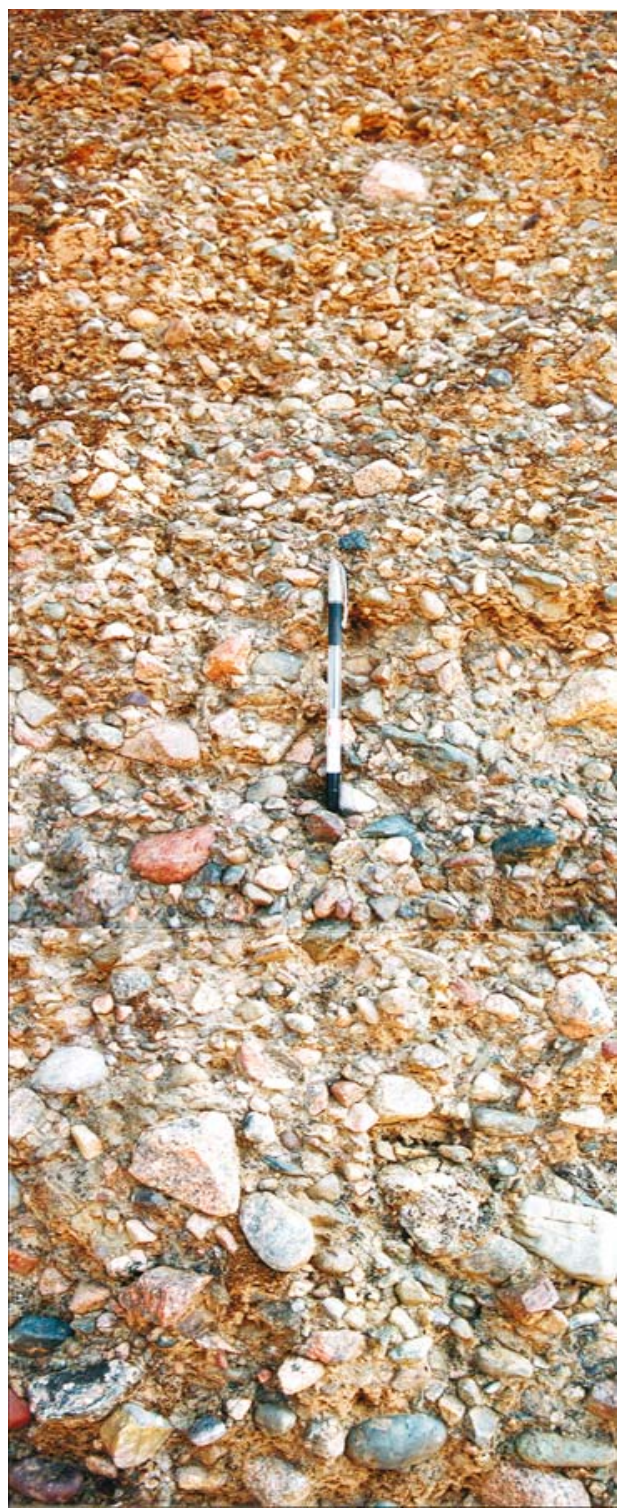

(a)

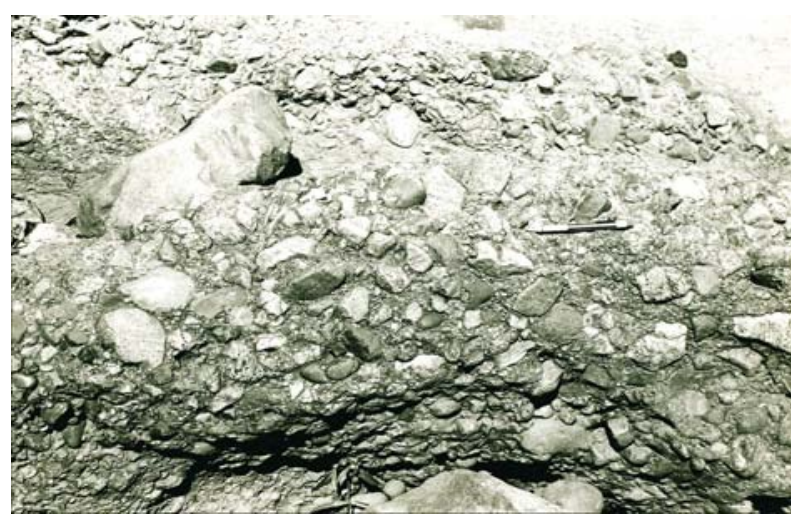

(b)

Figure 8. Clast-supported conglomerates of facies 1-C. Note: grain-to-grain contacts $(\mathbf{a}, \mathbf{b})$, matrix between clasts (b), normal-to-inverse grading (a) and inverse grading (b).

en-masse as the dispersive pressure decreased. Outsized clasts at bed boundaries are inferred

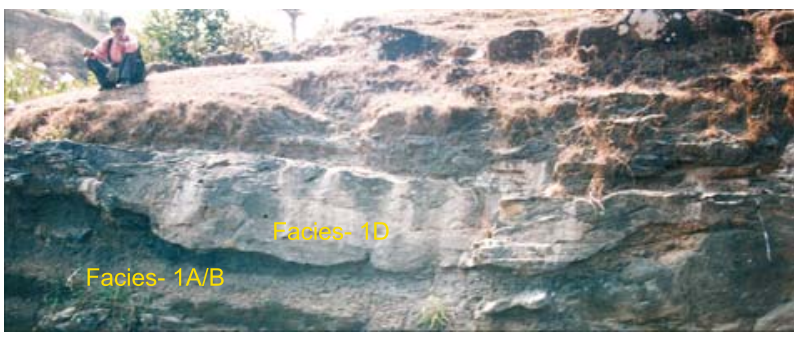

(a)

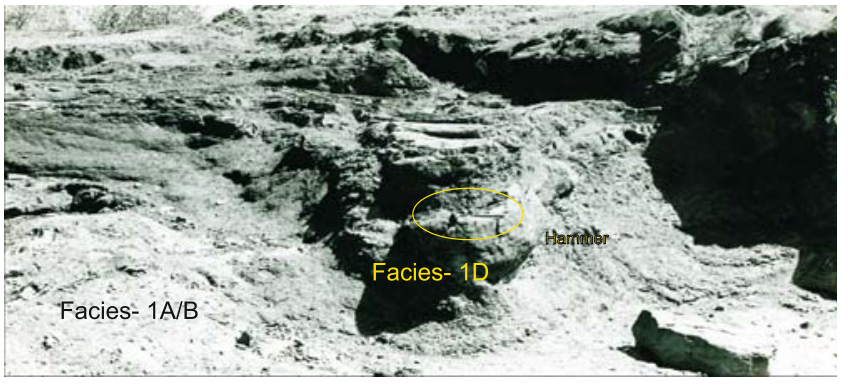

(b)

Figure 9. Channelised sandstone bodies (facies 1-D) within diamictities (facies 1-A/B). Note: basal scour, wings (a) and steep walls (b).

to be dropstones suggesting subaqueous grain flows.

\section{1.d Facies-1D (Subaqueous glacial melt-water channel/tunnel deposits)}

Description: This facies is represented by isolated, single-storeyed, medium-grained sandstone bodies with pebbles. The sandstone bodies are ribbon-shaped and show channel-form geometry with scoured, concave-upwards bases incising facies-1A/B conglomerate (figure 9). The upper boundaries are usually flat and are again overlain by facies-1A/B conglomerates. In profile, the bodies are a few to $20 \mathrm{~m}$ wide and their maximum thickness ranges between 0.5 and $5 \mathrm{~m}$. The bodies with moderate width:depth ratio usually have wings (figure 9a). On the other hand, bodies with low width:depth ratio show steep-sided walls (figure 9b). The sandstones may be massive or stratified showing cross-stratification and ripple cross-lamination.

Interpretation: The features of this facies indicate traction transport of sand-grade sediments by channelised fluid flows. The channels were evidently isolated, small in dimension, and subaqueous as they incise into and are overlain by subaqueous sediment gravity flow deposits. Steepwalled channel-fills resemble over-sized gutters. It is inferred that steep-walled channels were proximal to the source that widened downstream giving rise to sandstone bodies of high width:depth ratio with wings. 


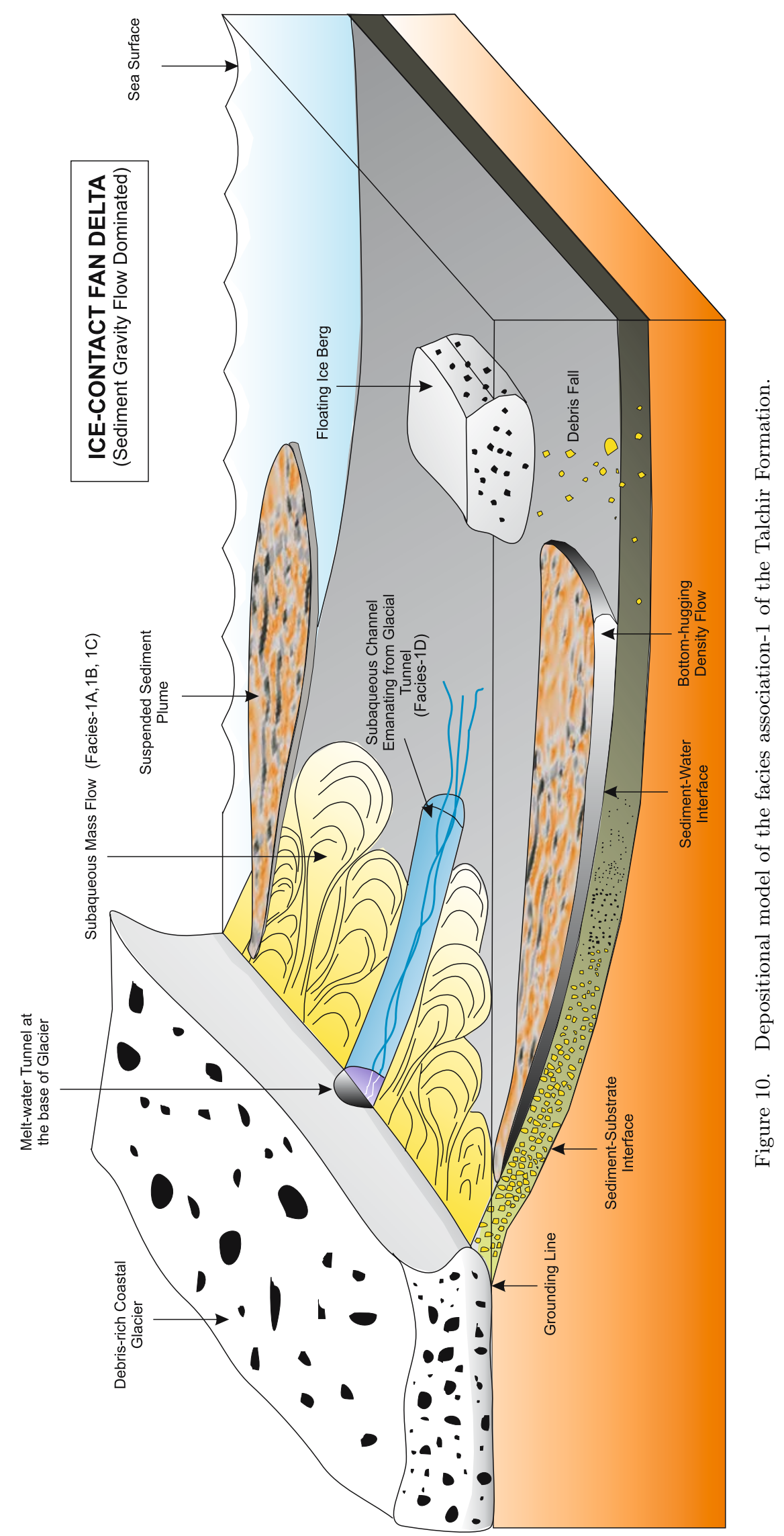




\section{1.e Summary of facies association-1}

All the facies described above occur in association with each other, laterally as well as vertically (figure 4). Individual facies represent different varieties of subaqueous sediment gravity flows. Subaqueous sediment gravity flows are common in fan deltas. Presence of features diagnostic of deposition under glacial regime suggests that final deposition of the sediments under the influence of gravity were probably intricately related with glacial processes. It is thus inferred that facies association-1 was deposited as glacigenic subaqueous fans that are variously termed ice-contact or grounding-line fan deltas or till deltas (figure 10; Alley et al 1987, 1989; Eyles et al 1989; Powell 1990; Eyles and Eyles 1992; Lonne 1995; Laberg and Vorren 2000; Lonne et al 2001; Lajeunesse and Allard 2002; Lonne and Nemec 2004). Piles of sediments dumped by glaciers at the grounding line were resedimented into the subaquatic realm due to gravity failure (Russel and Arnott 2003). Occurrence of dropstones indicates the presence of debris-charged floating icebergs that were calved from the main glacier (Miller 1996). Channelshaped sandstone bodies occurring within the sediment gravity flow deposits probably represent gullies formed by fluid jets emanating from the mouth of sub-glacial, melt-water tunnels at the grounding line (figure 10; Russel and Arnott 2003).

\subsection{Facies association-2 (Glacial outwash braidplain delta deposits)}

\section{2.a Facies-2A (Coarse-grained braided channel deposits)}

Description: Facies-2A is represented by multistoreyed, sheet-like pebbly sandstone and sandstone bodies (figure 11). Sediment bodies are prominently stratified. Stratification includes meter-scale cross-stratification and planar, horizontal stratification. Individual storeys at places show scoured bases. Locally the cross-strata may be oppositely oriented in successive sets. Outsized boulders occur rarely.

Interpretation: Multi-storeyed sheet sandstone bodies with scoured base, unimodal paleocurrent (figure 23) and abundance of cross as well as horizontal stratification suggest deposition from braided, bedload channels. Outsized boulders are inferred to be dropstones and point towards the subaquatic nature of the channels. Occurrence of oppositely oriented cross-strata suggests possible tidal influence.

The other facies of facies association 2 are represented by conglomerates similar to that of facies1A/B (mass flow deposits; figure 4). The overall

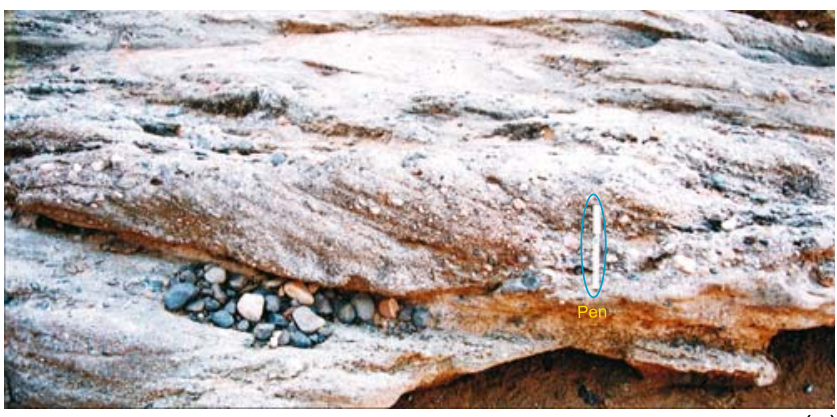

(a)

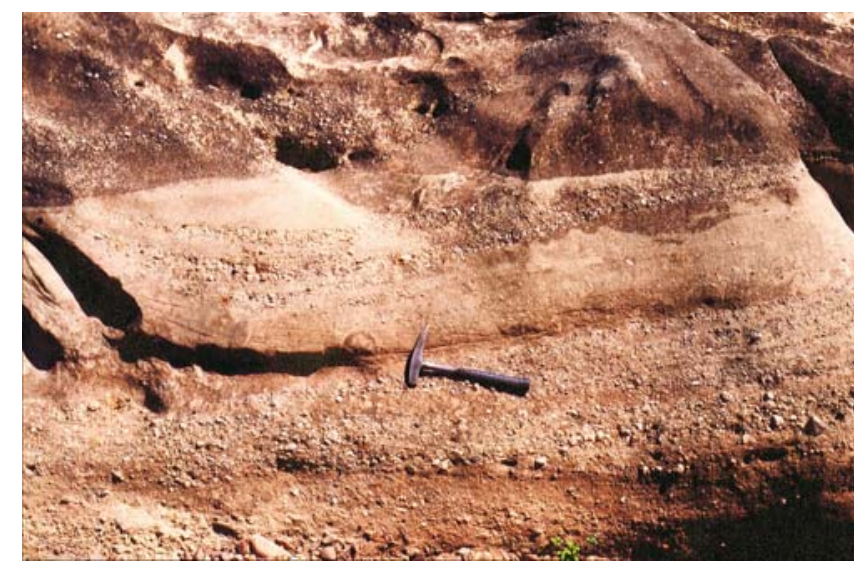

(b)

Figure 11. Cross-stratified pebbly sandstones of facies 2-A of the Talchir Formation. Note: lenticular shape and scoured bases.

depositional system is inferred to represent a braidplain delta depositional system, fed by a subaerial braidplain formed due to glacial outwash during melting and retreat of a continental ice sheet with occasional deposition from debris flows (figure 12). However, the record of subaerial braidplain is not preserved in the succession.

\subsection{Facies association-3}

(Wave-dominated shoreface-shelf deposits)

\section{3.a Facies-3A \\ (Storm-induced combined-flow deposits)}

Description: 5-15 m thick, sheet-like, mediumgrained, amalgamated sandstone bodies represent this facies. Internally the beds show low-angle $\left(<10^{\circ}\right)$ cross-strata that in profile appear as shallow, decimeter-to-meter scale intersecting sets of shallow troughs showing multi-directional dip azimuths in single outcrops and sections (figure 13). The cross-strata at places are draped by convex-upwards parallel-stratification. Symmetric and asymmetric meter-scale hummocky and swaley bedforms (wavelength: 5-10 metres, amplitude: 0.3 to 0.5 meters) are also common (figure 13 ). In places these are internally made up of ripple 


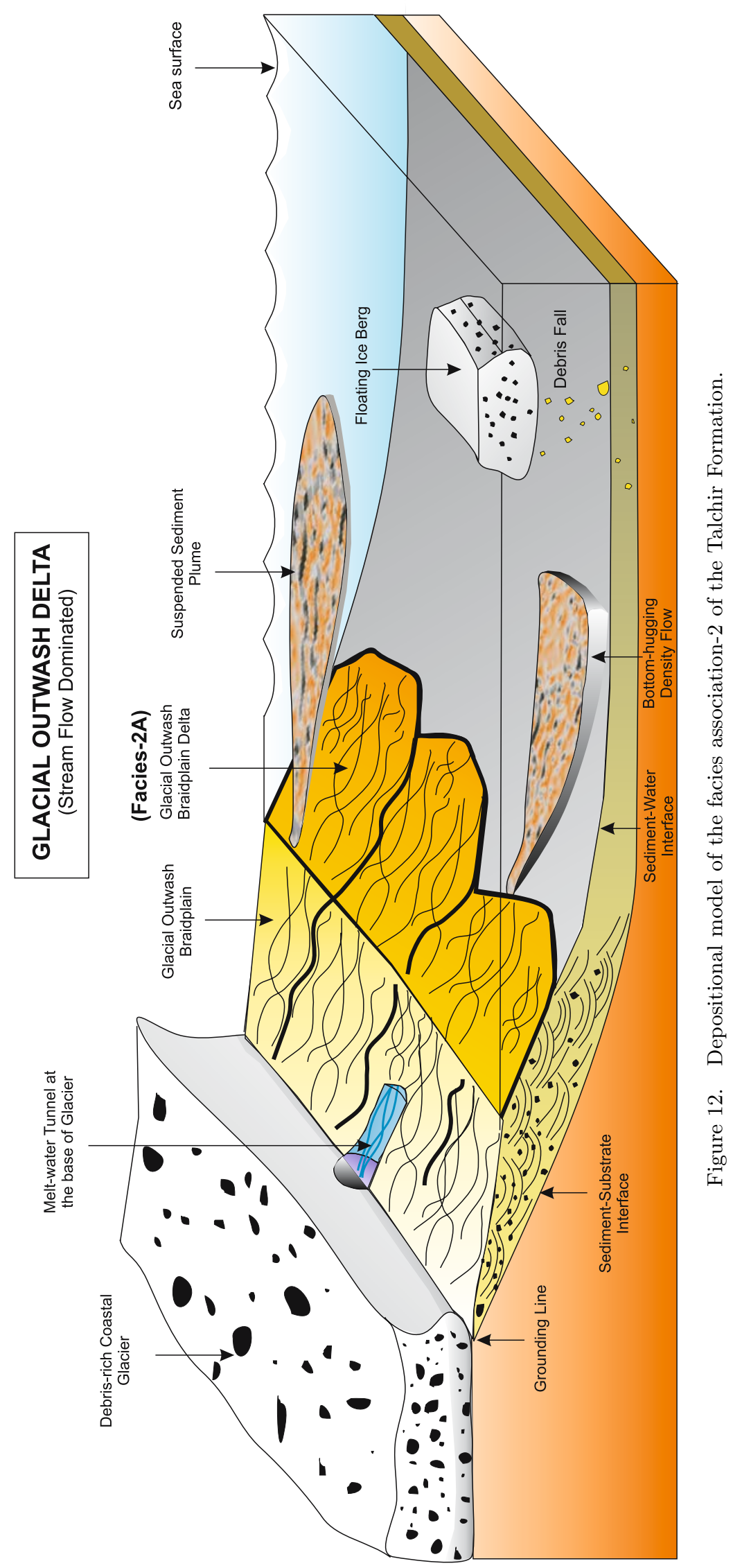



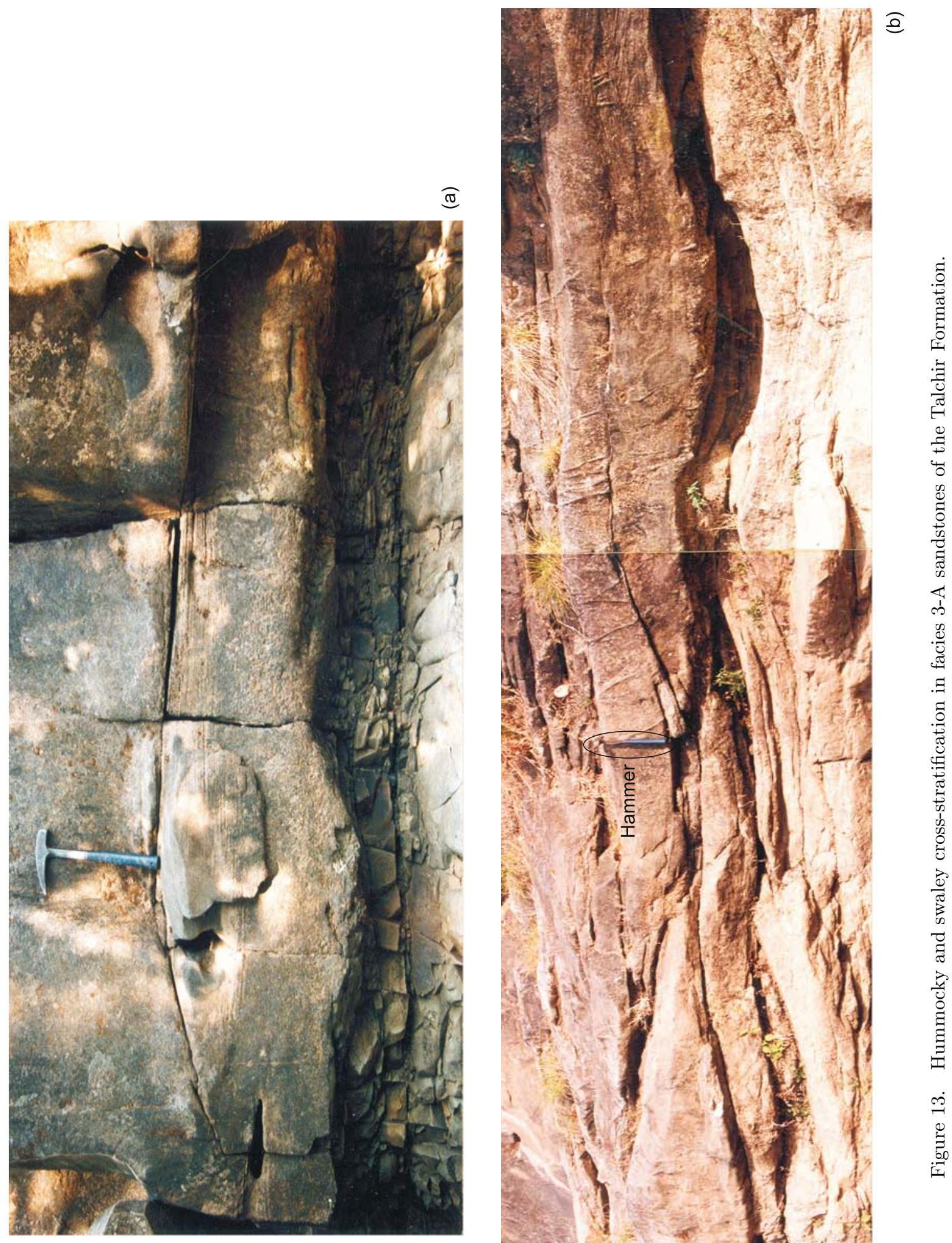


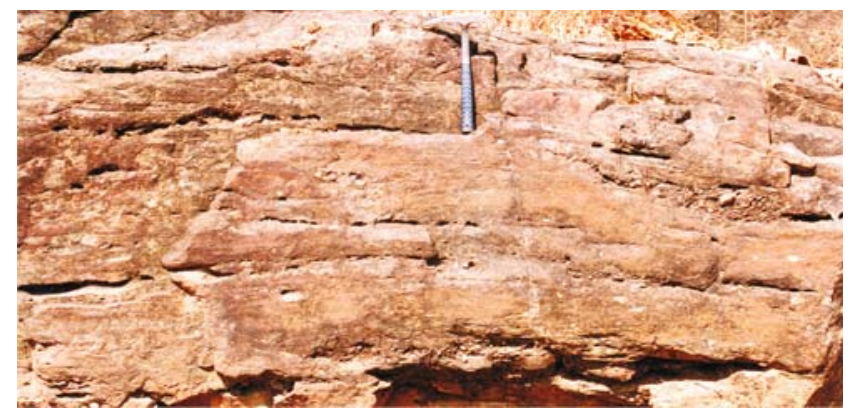

(a)

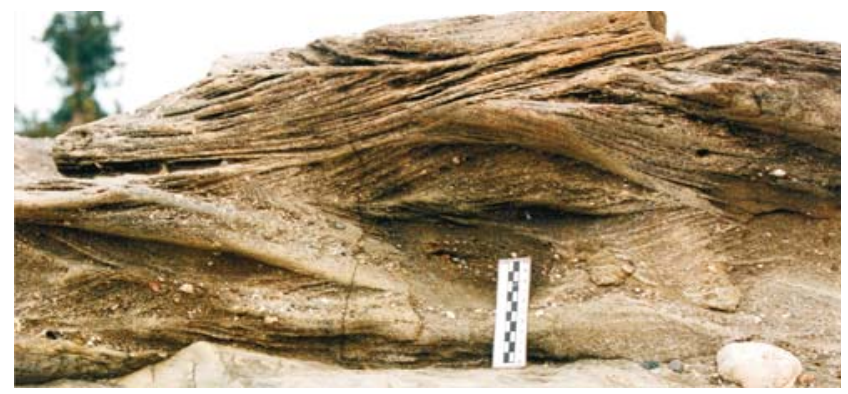

(b)

Figure 14. Upward-convex (a) and multi-directional cross-stratification (b) within facies 3-A pebbly sandstones of the Talchir Formation. Note: coarse-grained lithology, bundled-upbuilding, chevron-like arrangement and outsized clasts. Scale bar in (b) is $10 \mathrm{~cm}$ long.

lamination (quasi-planar lamination, cf. Arnott 1993). Locally the foresets of ripples in successive sets are oppositely oriented.

In places, facies 3 -A sediment bodies are represented by pebbly or granular medium-to-coarse sandstones showing all the sedimentary structures mentioned above along with out-sized boulders (figure 14). Between the stratified sandstone bodies there are laterally impersistent (1) normally graded intervals within the grain size range of granules, (2) stratified clast-rich conglomerates, (3) structureless pods of clast-supported conglomerates and (4) muddy matrix-supported conglomerates.

At places, the bed surfaces of this facies are marked by linear, parallel striations. Locally the beds are totally disrupted and fluidized. Slump folds and syn-sedimentary faults, boudins are common.

Interpretation: The cross-stratification style and their dimensions indicate a combined-flow origin (Arnott and Southard 1990; Van de Meene et al 1996; Myrow et al 2002), and the presence of hummocky cross-stratification and quasi-planar lamination suggests deposition from storm-generated flows under transitional upper-stage plane bed conditions (Arnott 1993). Superimposition of unidirectional currents on the storm-generated oscillatory flow resulted in a combined-flow structure that could sustain low-relief unidirectionally migrating

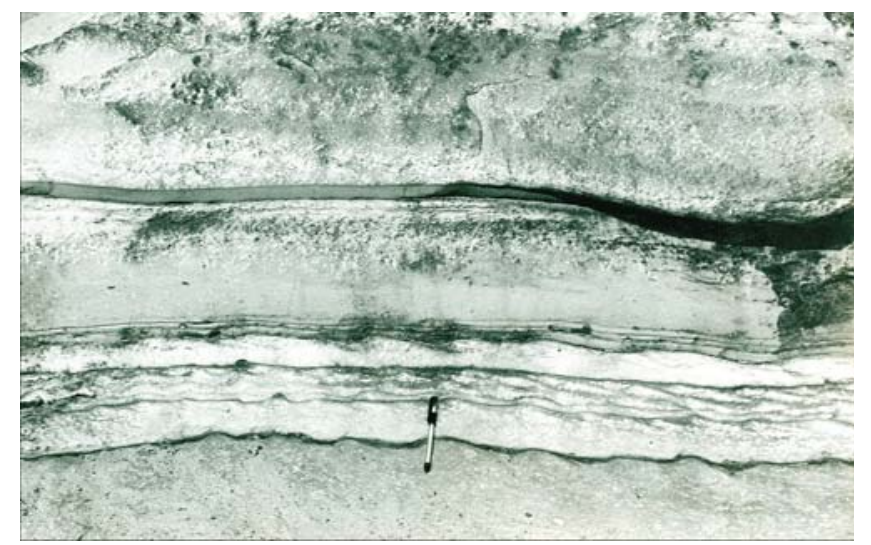

(a)

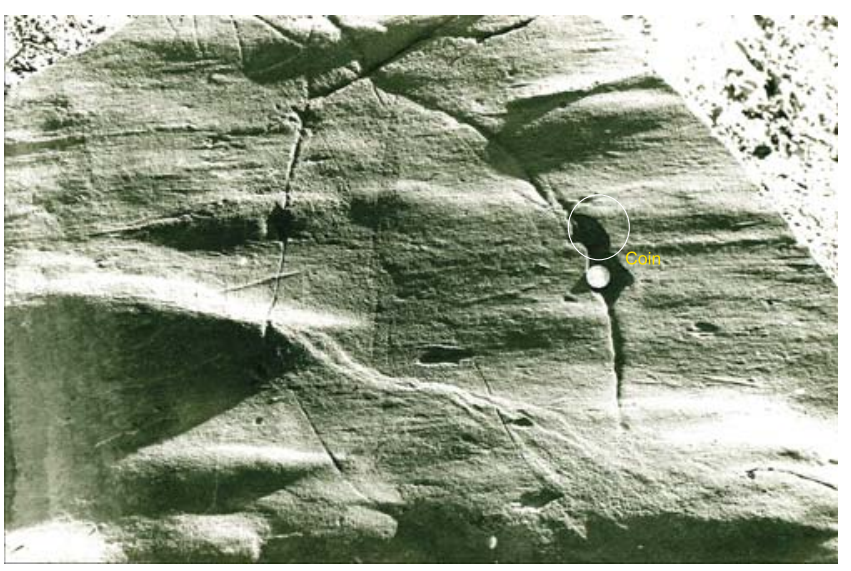

(b)

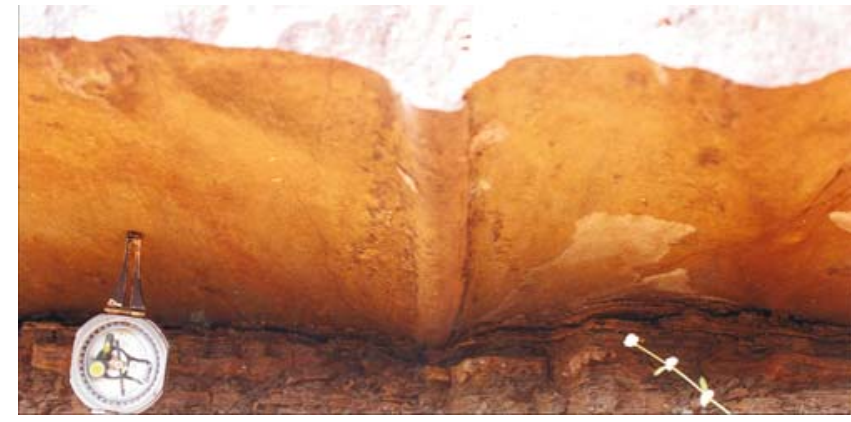

(c)

Figure 15. Sheet sandstones of facies 3-B of the Talchir Formation. Note: vertical variation from parallel-lamination to ripple-lamination and thin mudstone drapes (a), flute marks (b) and gutter casts at the bases (c).

bedforms superposed on asymmetric hummocky strata instead of typical, symmetrical, hummocky cross-stratification. A wave-dominated shoreface environment is inferred for this facies. Outsized boulders represent dropstones and indicate the presence of a few floating icebergs. The coarsergrained intervals of this facies are interpreted to represent reworking and resedimentation of icedumped debris by marine currents and waves (Eyles et al 1998). Linear striations on bed surfaces were probably formed by grounded icebergs that 


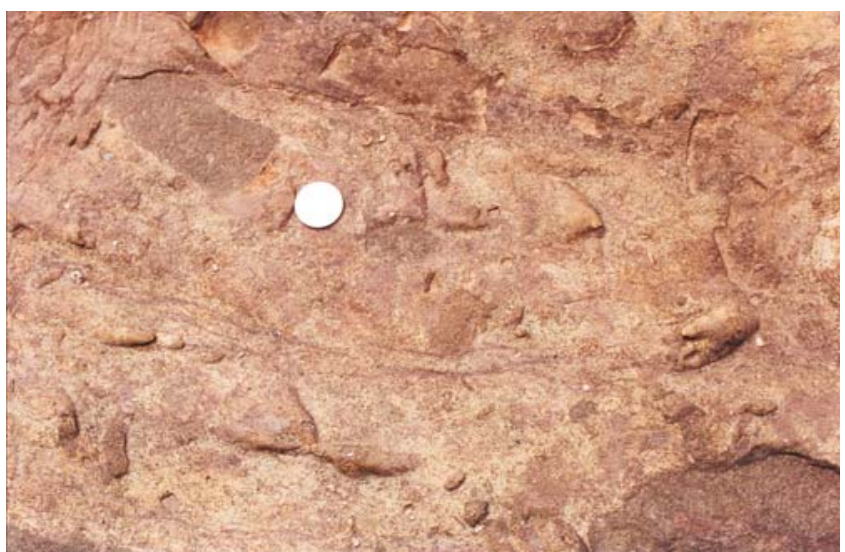

(a)

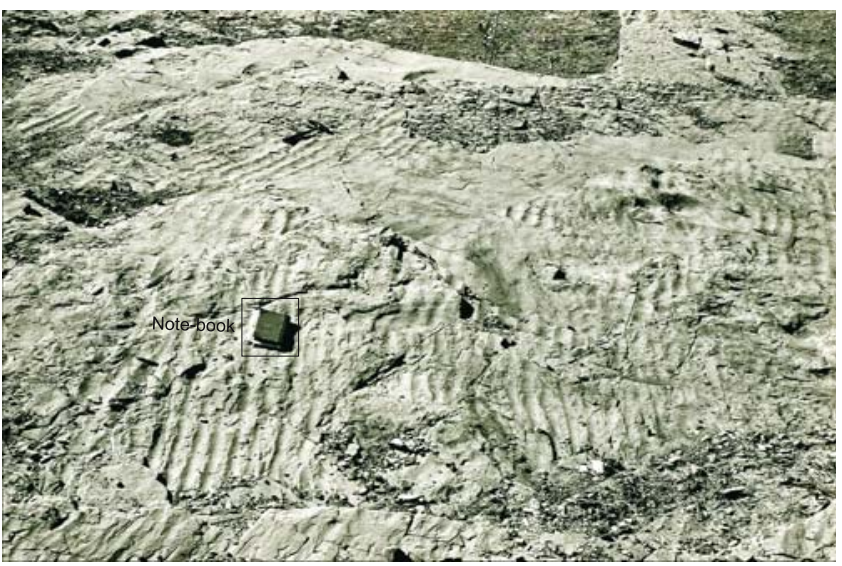

(b)

Figure 16. Diverse orientation of sole marks (a) and ripple crests (b) in facies 3-B sandstones of the Talchir Formation.

resulted in the observed deformational structures and cryoturbation. Bidirectionality of ripple crosslamination suggests tidal effects.

\section{3.b Facies-3B (Storm-induced hyperpycnal flow deposit)}

Description: This facies is represented by decimeter-scale, sheet-like sandstone beds with sole marks (gutter cast, flute cast, groove cast, prod mark) displaying progressive vertical variation in structure from horizontal parallel-lamination (parting lineated) to ripple lamination (figure 15). Thin mudstone layers often mark the interfaces of the sandstone beds. The sole marks are usually diversely oriented, and the ripples although asymmetric show diverse orientations with bifurcated crests (figure 16). Outsized clasts occur rarely.

Interpretation: This facies is inferred to represent tempestites or wave-modified turbidites (Myrow and Southard 1996; Myrow et al 2002). Diverse orientation of the sole marks indicates the influence of storm waves that modified downwelling sediment-laden storm-surge ebb currents. An inner

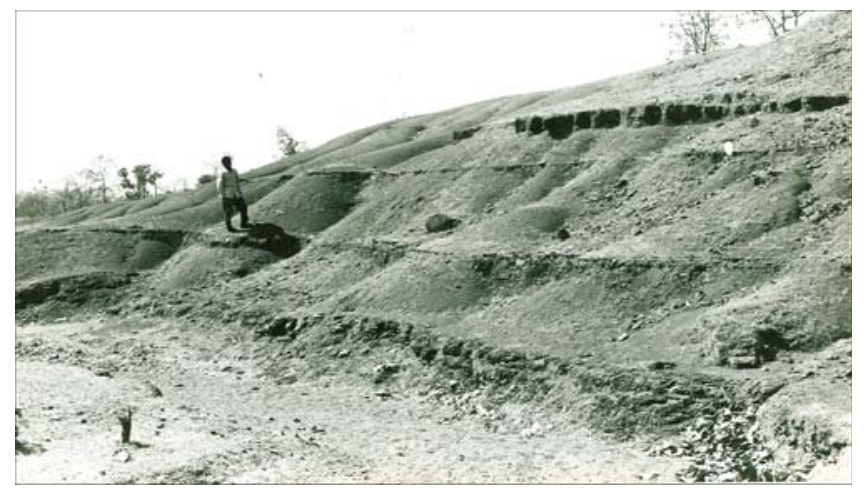

Figure 17. Talchir shales of facies 3C. Note: interbeds of coarser clastics within the shale.

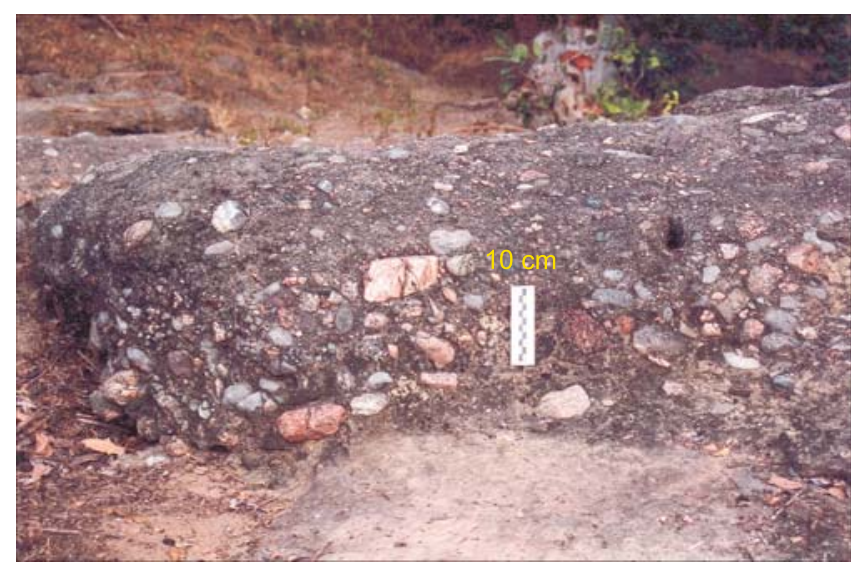

Figure 18. A normally graded conglomerate interbed within facies $3 \mathrm{C}$ shale of the Talchir Formation.

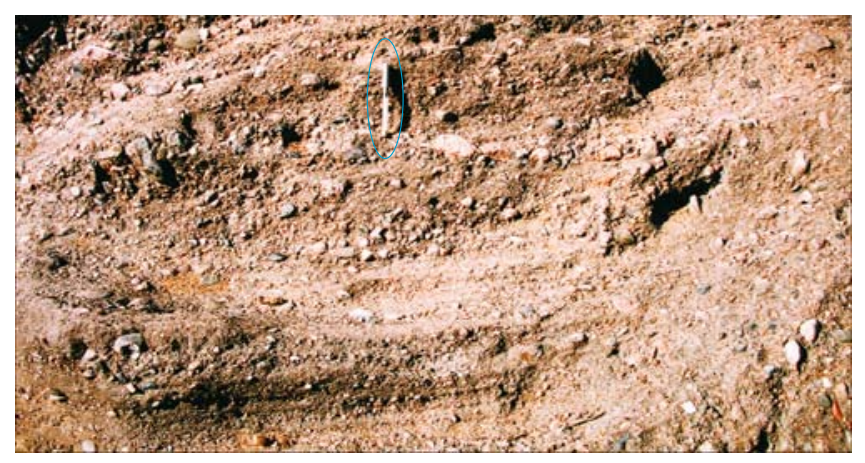

Figure 19. Traction carpet deposits within facies 3C shales of the Talchir Formation. Note crude parallel-stratification.

shelf setting is inferred for this facies. Outsized clasts are dropstones indicating the presence of a few icebergs.

\section{3.c Facies-3C (Outer shelf suspension fallout deposits)}

Description: The basic motif of this facies is represented by olive-green to black coloured claystone 


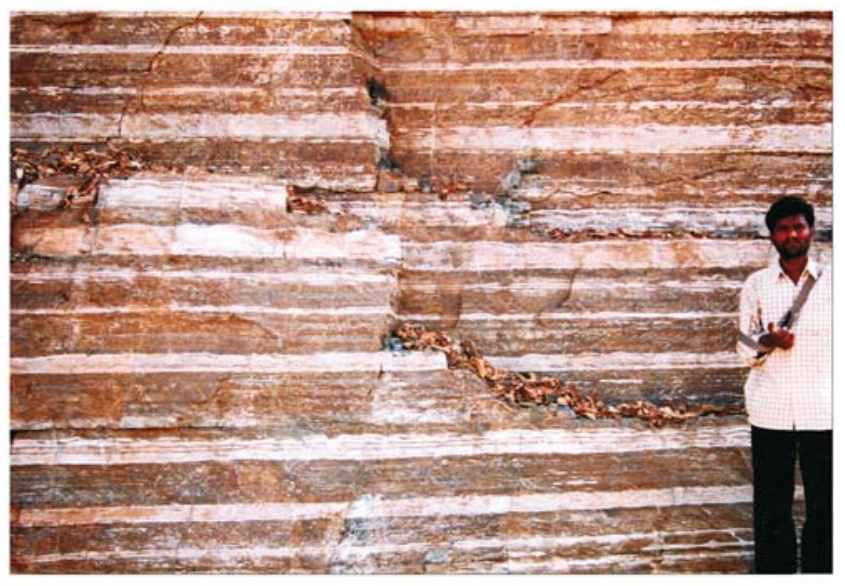

(a)

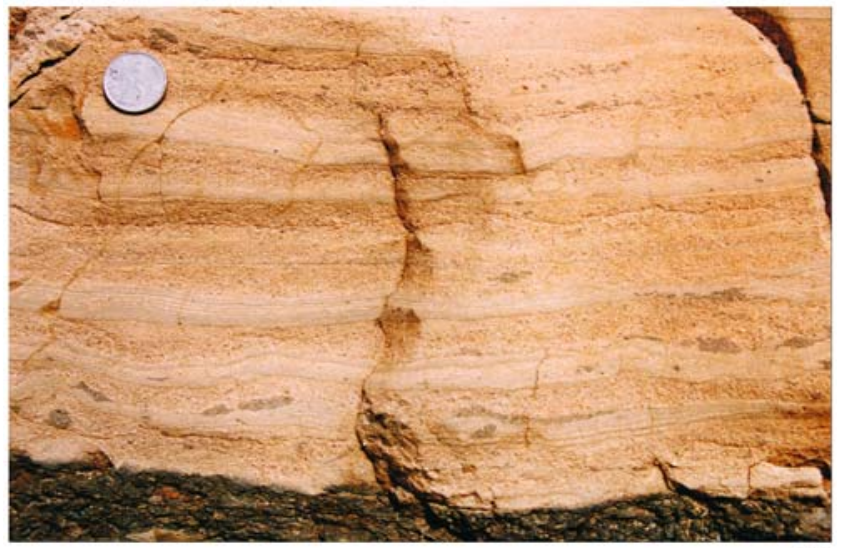

(b)

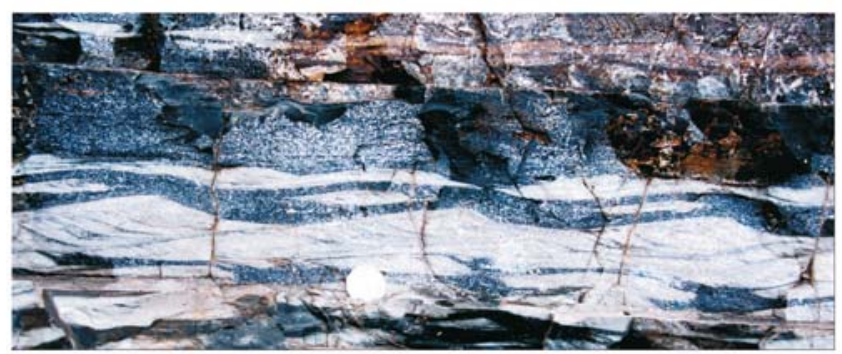

(c)

Figure 20. Turbidite beds within facies 3C shales of the Talchir Formation (a). Note: successive layers of normally-graded to parallel-laminated intervals (b) and climbing ripple cross-lamination (c).

(figure 17) with coarser-grained, decimeter to meter-scale interbeds. The claystones are usually massive and homogeneous, but at places show fissility planes. Thin $(1-15 \mathrm{~cm})$, laterally persistent micritic limestone layers, fractures filled with carbonates, and ellipsoidal carbonate nodules of diagenetic origin are also common. Gravel-sized clasts ranging in size mostly from granule to pebble are often dispersed within the claystones, which at places may be of boulder size.

Among the coarser-grained interbeds, some resemble facies $1-\mathrm{A}$ and $1-\mathrm{B}$. Besides these, there

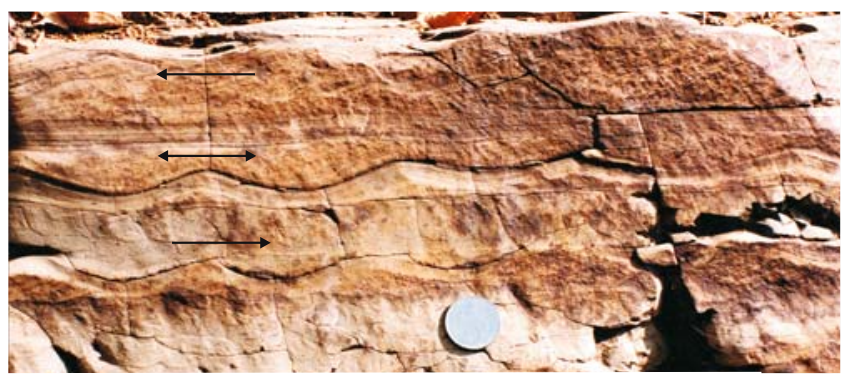

(a)
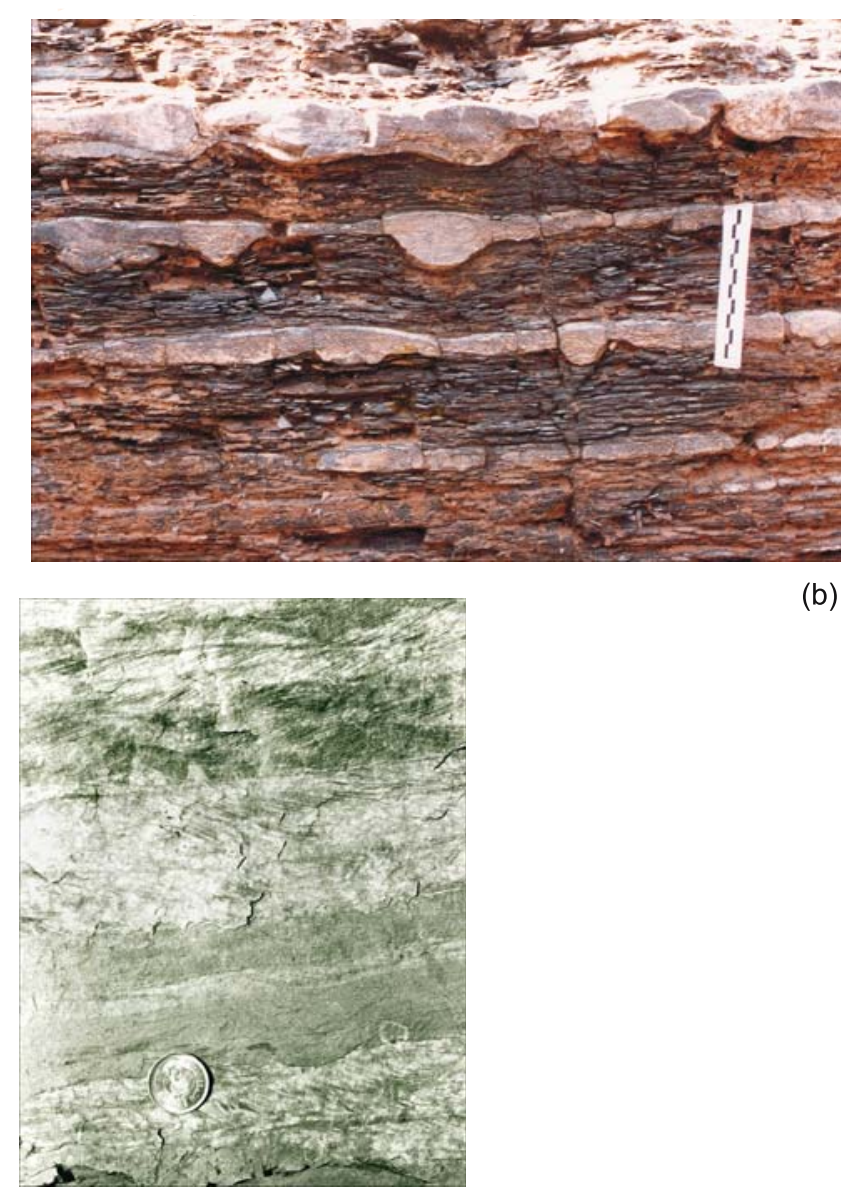

(b)

Figure 21. Internal features of turbidite beds within facies 3C shales of the Talchir Formation. Note: vertical variation from asymmetric ripple (right arrow) to symmetric ripple (double arrow) to oppositely oriented asymmetric ripple (left arrow) (a), laterally connected gutters (b) and oppositely oriented climbing ripple cross-lamination (c).

are also other types of interbeds of different thicknesses as described below:

- Granule- to pebble-conglomerates and very coarse- to coarse-sandstones embedded within facies 3C claystones. The conglomerates are clast-supported. The beds have scoured bases and show normal grading (figure 18). Some sandstone beds appear to be massive and ungraded. 


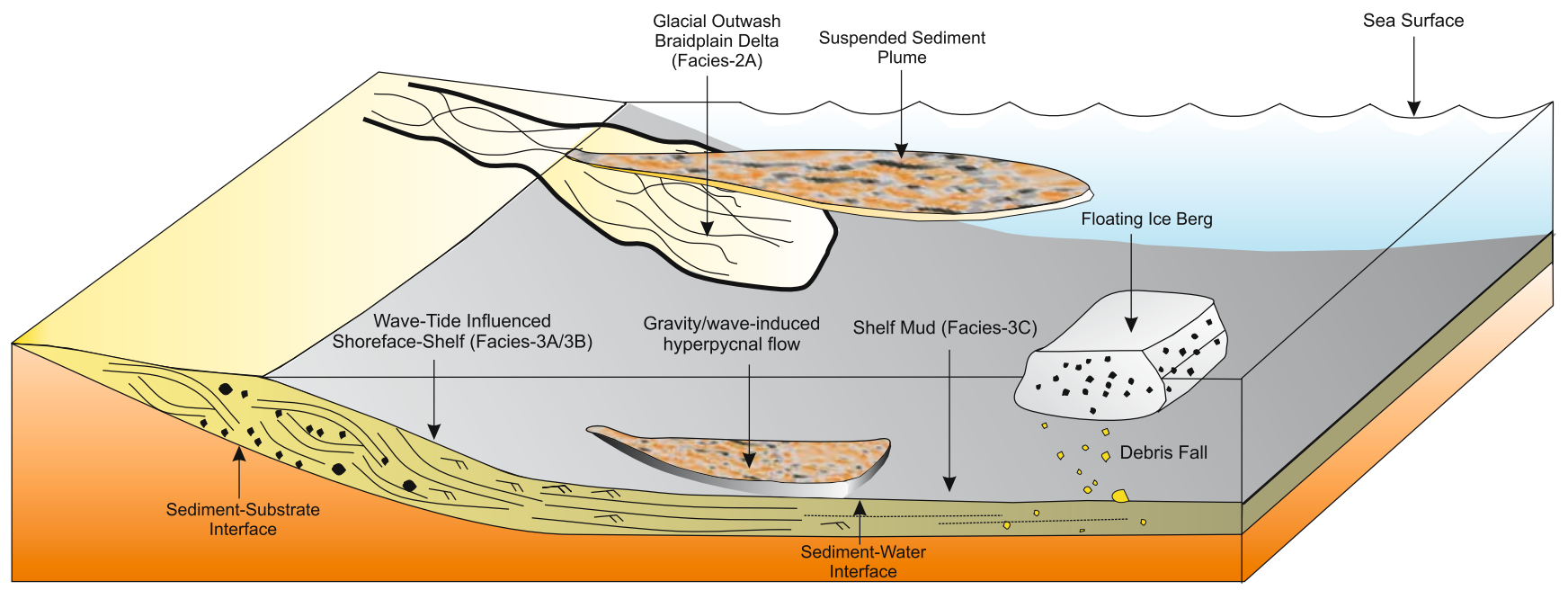

Figure 22. Depositional model of the facies association-3 of the Talchir Formation.

- Pebbly, coarse sandstone beds wherein the percentage of gravelly clasts varies from 5 to 25 . The beds show diffuse to well-defined parallel-stratification (figure 19). Clasts are often aligned defining one-pebble thick layers within laminated sandstones.

- Sheet-like, laterally persistent, decimeter-scale siliciclastic or calcareous fine- to mediumsandstone beds internally showing Bouma-type sequences with all or one of the divisions $(\mathrm{A}, \mathrm{B}, \mathrm{C}$ etc.; figure 20). The beds have sharp bases showing a variety of sole marks including flutes. The beds may occur singularly encased within facies3C claystone, but at places may be stacked successively with thin claystone intervals to form a succession of up to 10 meters. There is another variety in which the ripples of the C-division of the Bouma sequence may be symmetric in profile and in bedding plane appear to be diversely oriented and show crest bifurcation (figure 21). Among the sole marks gutter cast is dominant (figure 21). Moreover, the flutes and prod marks are diversely oriented. In one location, a calcareous bed of this facies yielded abundant bivalves (cf. Ghosh 2003). The foresets within successive ripple-laminated beds may be oppositely oriented (figure 21).

Interpretation: The features of this facies indicate suspension fallout of mud particles in deep water from hypopycnal sediment plumes. The depositional environment is inferred as inner to outer shelf. Dispersed gravels were deposited from floating icebergs. The coarser interbeds, many of which are calcareous, were emplaced by a variety of sediment gravity flows such as debris flow, concentrated density flow, traction carpet (Hiscott 1994; Sohn 1997, 2003) and turbidity currents affected by storm waves and tidal currents that occasionally penetrated a deep shelf environment.

\section{3.d Summary of facies association-3}

The facies association-3 overall depicts an open marine, wave-dominated but tide-affected shelf depositional system comprising deposits formed both within fair-weather wave base (i.e., shoreface; facies-3A) and below (i.e., shelf; facies 3B and 3C). In contrast to facies associations 1 and 2 , this facies association represents a paleogeography that was neither deltaic nor were there significant glacial influences (figure 22). However, scarce presence of dropstones suggests a few small icebergs, the remnants of the vast ice sheet that decayed with time. The different sediment gravity flow deposits resulted from resedimentation of relict sediment aprons from the shoreline.

\section{The Talchir depositional regime}

The different marine facies of the Talchir Formation define a number of shallowing-upward packages, which are arranged in the succession with a retrogradational trend to result in an overall fining- and deepening-upward succession (figure 4). The overlying Barakar Formation, containing coal beds, has been interpreted to have formed in a tide-wave influenced deltaic setting with a marine, prodeltaic part (Ghosh et al 2004). The strata 


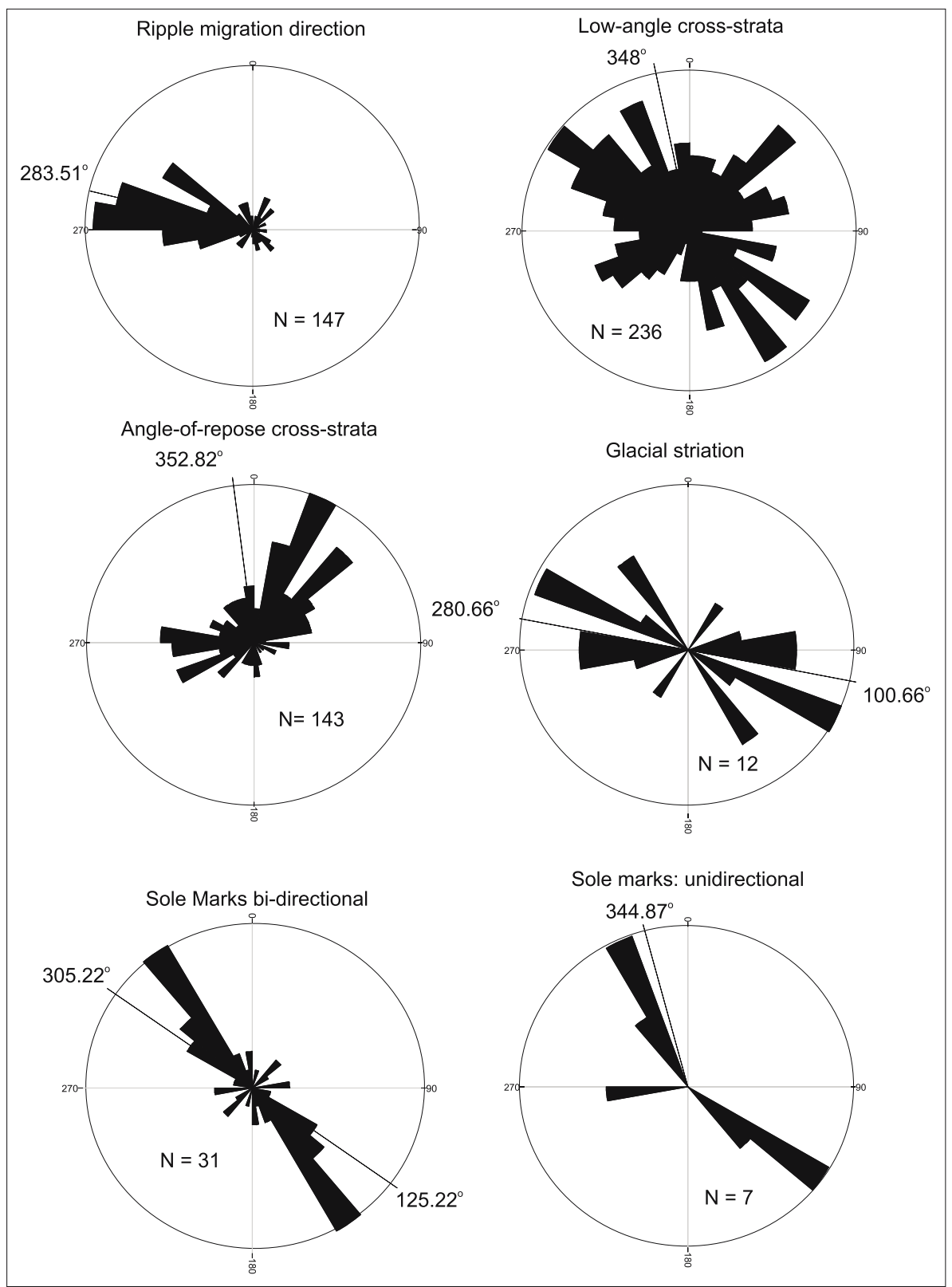

Figure 23. Overall paleocurrent pattern obtained from the Talchir Formation.

that are transitional between Talchir and Barakar Formations show preservation of abundant plant materials suggesting gradual warming. The three facies associations of the Talchir Formation also point towards progressive decrease in the volume of glacier inducing changes in the paleogeography from ice-contact fan delta to braidplain delta to a virtually ice-free, non-deltaic open marine realm. It follows that the Talchir-Barakar succession overlying the Precambrian basement, as a whole, represents a continuum of sedimentation in a marine basin. The retrogradational Talchir Formation developed in a glacio-marine realm under a transgressive systems tract and was overlain by the progradational Barakar Formation that developed in a fluvio-deltaic regime under a highstand systems tract. The overall paleocurrent pattern indicates northerly sediment transport (figure 23).

\section{Conclusions}

The findings of the present study can be summarised through the following points:

- Although continental glacial deposits are not present, the Talchir Formation of the Satpura basin is replete with features indicating deposition in a glacial regime. 
- Presence of tidal signatures and marine fossils suggests a proglacial marine environment.

- The bulk of the lower part of the Talchir succession was emplaced by resedimentation of debris dumped by glaciers at the shoreline. The resedimentation process involved a variety of sediment gravity flows including debris flow, hyperconcentrated/concentrated mass flow, subaqueous grain flow, turbidity current as well as hypopycnal sediment plumes.

- The upper part of the succession is dominated by deposits of storm-generated flows.

- The inferred depositional systems include icecontact fan delta, outwash braidplain delta and a virtually ice-free, non-deltaic open marine realm. The products of individual systems occur repetitively in the succession. The changeover from one system to the other was related to periodic glacial advance and retreat.

- The strata that are transitional between the Talchir and the overlying Barakar Formation show preservation of abundant plant materials suggesting gradual warming and deglaciation.

- The overall sediment transport direction is found to be northerly, across the trend of syn-sedimentary faults that induced subsidence during the early phase of basin evolution (Chakraborty and Ghosh 2005).

\section{Acknowledgements}

Financial assistance from the Department of Science \& Technology, New Delhi and Indian Statistical Institute is gratefully acknowledged. We are grateful to the Western Coalfields Limited, Pench-Kanhan Valley, M.P., for arranging accommodation during fieldwork. Indian Statistical Institute, Kolkata provided infrastructural facilities. Constructive criticism by the two reviewers are greatly appreciated.

\section{References}

Alley R B, Blankenship D D, Bentley C R and Roony S T 1987 Till beneath ice stream B3; J. Geophys. Res. 92 8921-8929.

Alley R B, Blankenship D D, Roony S T and Bentley C R 1989 Sedimentation beneath ice shelves: the view from the Ice Stream B; Marine Geol. 85 101-120.

Arnott R W C 1993 Quasi-planar-laminated beds in the lower Cretaceous Bootlegger member, north-central Montana: evidence of combined-flow sedimentation; J. Sedim. Petrol. 63 488-494.

Arnott R W C and Southard J B 1990 Exploratory flowduct experiments on combined flow bed configurations, and some implication for interpreting storm-event stratification; J. Sedim. Petrol. 60 211-219.
Biswas S K 1999 A review on the evolution of rift basins in India during Gondwana with special reference to western Indian basins and their hydrocarbon prospects; In: Proc. Indian National Sci. Acad. Special issue on Gondwana assembly: new issues and perspectives (eds) Sahni A and Loyal R S, pp. 261-283.

Biswas S K 2003 Regional Tectonic framework of the Pranhita-Godavari basin, India; J. Asian Earth Sci. 21 543-551.

Brodzikowski K and Van Loon A J 1987 A systematic classification of glacial and periglacial environments, facies and deposits; Earth Sci. Rev. 24 297-381.

Casshyap S M and Qidwai H A 1974 Glacial sedimentation of late Palaeozoic Talchir diamictite, Pench valley coalfield, central India; Geol. Soc. Am. Bull. 85 749-760.

Chakraborty C and Ghosh S 2005 Pull-apart origin of the Satpura Gondwana basin, central India; J. Earth Sys. Sci. 114 259-273.

Chakraborty C, Mandal N and Ghosh S 2003 Kinematics of the Gondwana basins of peninsular India; Tectonophys. 377 299-324.

Crawford A R 1978 Narmada-Son lineament of India traced into Madagascar; J. Geol. Soc. India 19 144-153.

Crowell J C and Frakes L A 1975 Late Paleozoic glaciation; In: Gondwana Geology (ed.) Campbell K S W, Australian National University Press, Canbera, pp. 313-331.

Crowell J C 1995 The ending of the late Paleozoic Ice Age during the Permian period; In: Paleogeography, paleoclimates, stratigraphy (eds) Scholle P A, Peryt T M and Ulmer Scholle D S (Berlin: Springer-Verlag) 62-74 pp.

Das B and Patel N P 1984 Nature of the Narmada-Son lineament; J. Geol. Soc. India 25 267-276.

Enos P 1977 Flow regimes in debris flow; Sedimentology 24 133-142.

Eyles C H, Eyles N and Gostin V A 1998 Facies and allostratigraphy of high latitude, glacially influenced marine strata of the early Permian southern Sydney basin, Australia; Sedimentology 45 121-161.

Eyles C H, Mory A J and Eyles N 2003 CarboniferousPermian facies and tectono-stratigraphic successions of the glacially influenced and rifted Carnarvon basin, western Australia; Sedim. Geol. 155 63-86.

Eyles N and Eyles C H 1992 Glacial depositional systems, In: Facies models: Geotext 1 (eds) Walker R G and James N P, Geological Association of Canada, 73-100 pp.

Eyles N, Eyles C H and McCabe A M 1989 Sedimentation in an ice-contact subaqueous setting: the mid-Pleistocene "North Sea drifts" of Norfolk, UK; Quaternary Science Reviews 8 57-84.

Eyles N, Mory A J and Eyles C H 2002 CarboniferousPermian palynostratigraphy of west Australian marine rift basins: resolving tectonic and eustatic controls during Gondwanan glaciations; Paleogeography, Paleoclimatology, Paleoecology 184 305-319.

Ghosh S K 2003 First record of marine bivalves from the Talchir Formation of the Satpura Gondwana basin India: palaeobiogeographic implications; Gondwana Res. (Gondwana Newsletter Section) 6(2) 312-320.

Ghosh S K, Chakraborty C and Chakraborty T 2004 Combined tide and wave influence on sedimentation of Lower Gondwana coal measures of central India: Barakar Formation (Permian), Satpura Basin; J. Geol. Soc. London 161 117-131.

Gonzalez-Bonorino G and Eyles N 1995 Inverse relation between ice extent and the late Paleozoic glacial record of Gondwana; Geology 23 1015-1018.

Gravenor C P, Von Brunn V and Dreimanis A 1984 Nature and classification of waterlain glaciogenic sediments, 
exemplified by Pleistocene, late Paleozoic and late Precambrian deposits; Earch Sci. Rev. 20 105-166.

Hiscott R N 1994 Traction-carpet stratification in turbidites - fact or fiction?; J. Sedim. Res. A65 204-208.

Hobday D K 1987 Gondwana coal basins of Australia and South Africa; tectonic setting, depositional systems and resources; In: Coal and coal-bearing strata: recent advances (ed) A C Scott, Geol. Soc. London Spec. Publ. 32 219-233.

Jones M E and Preston R M F 1987 Deformation of the sediment and sedimentary rocks; Geol. Soc. London Spec. Publ. (Oxford, Blackwell: Scientific publications) 29 $1-350$.

Laberg J S and Vorren T O 2000 Flow behaviour of the submarine glacigenic debris flows on the Bear Island Trough mouth fan, western Barents Sea; Sedimentology $\mathbf{4 7}$ $1105-1117$.

Lajeunesse P and Allard M 2002 Sedimentology of an icecontact fan complex, Nastapoka Hills, eastern Hudson Bay, northern Quebec; Sedim. Geol. 152 201-220.

Lonne I 1995 Sedimentary facies and depositional architecture of ice-contact glaciomarine systems; Sedim. Geol. 109 13-35.

Lonne I and Nemec W 2004 High-arctic fan delta recording deglaciation and environment disequilibrium; Sedimentology $\mathbf{5 1} 553-589$.

Lonne I W, Nemec, Blikra L H and Lauritsen T 2001 Sedimentary architecture and dynamic stratigraphy of a marine ice-contact system; J. Sedim. Res. 71 922-943.

Lowe D R 1982 Sediment gravity flows: II. Depositional models with special reference to the deposits of highdensity turbidity currents; J. Sedim. Petrol. 52 279-297.

Major J J 1997 Depositional processes in large-scale debrisflow experiments; J. Geol. 105 345-366.

Miller J M G 1996 Glacial sediments; In: Sedimentary environments: processes, facies and stratigraphy; (ed.) Reading H G, Blackwell Science, pp. 454-484.

Mulder T and Alexander J 2001 The physical characters of subaqueous sedimentary density flows and their deposits; Sedimentology 48 269-299.

Myrow P M and Southard J B 1996 Tempestite deposition; J. Sedim. Res. 66a $875-887$.

Myrow P M, Fisher W and Goodge J W 2002 Wave-modified turbidites: combined-flow shoreline and shelf deposits, Cambrian, Antarctica; J. Sedim. Res. 72 641-656.

Powell R D 1990 Glacimarine processes at groundingline fans and their growth to ice contact deltas;
In: Glacimarine environments: processes and sediments; (eds) Dowdeswell J A and Scourse J D, Geological Society Special Publiclation 53 53-73.

Robinson P L 1967 The Indian Gondwana Formations A review; First Symposium on Gondwana Stratigraphy, Ar Del Plata, Argentina, 201-268.

Russel H A J and Arnott R W C 2003 Hydraulic jump and hyperconcentrated-flow deposits of a glacigenic subaqueous fan: Oak Ridge Moraine, southern Ontario, Canada; J. Sedim. Res. 73 887-905.

Sohn Y K 1997 On traction-carpet sedimentation; J. Sedim. Res. 67 502-509.

Sohn Y K 2003 Transformation of cohesive and noncohesive debris flows in subaerial and subaqueous settings; Geophysical Research Abstract, European Geophysical Society 502030.

Sohn Y K, Rhee C W and Kim B C 1999 Debris flow, hyperconcentrated flood-flow deposits in an alluvial fan, northwestern part of the Cretaceous Yongdong Basin, central Korea; J. Geol. 107 111-132.

Thomas G S P and Connel R J 1985 Iceberg drop, dump, and grounding structures from Pleistocene glaciolacustrine sediments, Scotland; J. Sedim. Petrol. 55 243-249.

Vallance J W and Scott K M 1997 The Osceola mudflow from Mount Rainier: sedimentology and hazard implications of a huge clay-rich debris flow; Geol. Soc. Amer. Bull. 109 143-163.

Van de Meene J W H, Boersma J R and Terwindt J H J 1996 Sedimentary structures of combined flow deposits from the shoreface-connected ridges along the central Dutch coast; Marine Geol. 131 151-175.

Veevers J J 2004 Gondwanaland from 650-500 ma assembly through 320 ma merger in pangea to $185-100$ ma breakup supercontinental tectonics via stratigraphy and radiometric dating; Earth Sci. Rev. 68 1-132.

Veevers J J and Powell C M C A 1987 Late Paleozoic glacial episodes in Gondwanaland reflected in transgressiveregressive depositional sequences in Euramerica; Geol. Soc. Am. Bull. 98 475-487.

Veevers J J and Tewari R C 1995 Gondwana master basin of Peninsular India between Tethys and the interior of the Gondwanaland Province of Pangea; Memoir Geological Society of America 187 1-73.

Wan Z and Wang Z 1994 Hyperconcentrated flow; International Association of Hydraulic Research A.A. Balkema, Rotterdam, p. 1-290. 